\title{
Trade openness, real exchange rates and job reallocation: evidence from Belgium
}

\author{
Italo Colantone
}

Published online: 7 July 2012

(C) The Author(s) 2012. This article is published with open access at Springerlink.com

\begin{abstract}
This paper investigates the impact of real exchange rate movements on job reallocation at the industry level. The analysis focuses on the manufacturing sector of Belgium, using data for 82 NACE 3-digit industries, over the time span 1996-2002. I find that real exchange rate changes do have a significant impact on job flows, and that this impact is magnified by increasing levels of trade exposure. In particular, a real appreciation is found to lower net employment growth through higher job destruction, while job creation is not significantly affected. These results are in line with previous empirical evidence on the United States, and differ from earlier findings for France and Germany, where the adjustment to real exchange rate shocks has been found to occur mainly through the job creation margin. I suggest that these differences may be explained by the fact that Belgium is a small open economy.
\end{abstract}

Keywords Trade openness $\cdot$ Real exchange rates $\cdot$ Job reallocation

JEL Classification $\mathrm{F} 16 \cdot \mathrm{F} 4$

\section{Introduction}

In today's global economy, domestic firms and workers in each country have become increasingly sensitive to international competition. This has induced the emergence of serious concerns about the labor market's drawbacks of globalization. Such issues figure prominently in the agenda of policy makers around the world. A good illustration of this is the current political pressure, especially exerted by the US and the EU, towards a revaluation of the Chinese renminbi. Indeed, the Chinese government is accused of keeping the value of its currency deliberately

I. Colantone ( $\square)$

Erasmus University Rotterdam, Burgemeester Oudlaan 50, Rotterdam, The Netherlands e-mail: colantone@ese.eur.nl 
undervalued, in order to grant Chinese firms a competitive advantage on the export markets. And yet, recent reports are showing that China has been displaying a substantial appreciation in real terms lately, due to the relatively high increase in wages, thus emphasizing the importance of looking at real exchange rates, besides nominal ones. ${ }^{1}$ This paper studies the impact of real exchange rate movements on net and gross job flows at the industry level, focusing on the manufacturing sector of Belgium, for the time span 1996-2002.

In a context of increasing trade openness, firms are expected to become more responsive to variations in real exchange rates, which reflect the relative prices of competing goods on the international markets (Gourinchas 1998). Indeed, real exchange rates can be seen as synthetic indicators of the competitiveness of domestic firms relative to their foreign competitors. In particular, real exchange rates are influenced by the evolution of nominal exchange rates and by the relative price dynamics across countries. Thus, they capture the influence of monetary policy and currency trading on the financial market, but also the effects of relative costs and productivity dynamics, which are finally reflected in prices.

Until now, only a few papers have studied the relation between real effective exchange rates and job flows: Gourinchas $(1998,1999)$ on the US and France, respectively, Klein et al. (2003a) on the US, and Moser et al. (2010) on Germany. All these studies have found that real appreciations have a negative impact on net employment growth, and that this impact is magnified by increasing levels of trade exposure, at the firm and industry level. However, differences have been found with respect to the adjustment process, which may work mainly through lower job creation (France and Germany) or through higher job destruction (US), depending on the specific context. Building on this literature, this paper aims at deepening our understanding of the impact of real effective exchange rates on job flows, by focusing, for the first time, on a small open economy such as Belgium.

Belgium constitutes a very interesting case study for this research question. Indeed, it is one of the most open economies in the world, and has experienced the highest increase in trade exposure among the EU countries over the considered period. ${ }^{2}$ Moreover it is characterized by strong labor market rigidities, which are typical of EU continental economies. ${ }^{3}$ Finally, very good data are available at the firm level for the Belgian manufacturing sector, allowing to carry a micro-founded analysis by relying on a large data set. ${ }^{4}$

\footnotetext{
${ }^{1}$ See, in particular, "Nominally cheap or really dear?" The Economist, November 6th-12th 2010, page 85.

${ }^{2}$ According to OECD data, the trade(in goods)-to-GDP ratio has grown from 1.13 to 1.30 between 1996 and 2002. This represents the highest increase among the EU Members.

3 According to the OECD Overall Index for the Strictness of Employment Protection, Belgium ranked 24th out of 28 industrialized countries in 1996. A higher level of protection was displayed only by Turkey, Portugal, Italy and Greece (OECD 2004). Following some changes in the legislation, the Strictness Index has slightly decreased over time (Ochel 2009). And yet, in 2002 Belgium still ranked 19 th out of 28 countries, with a level of strictness just above the one of Germany and the Netherlands (OECD 2004).

${ }^{4}$ See Abraham et al. (2009) for an earlier application.
} 
The empirical analysis is based on the theoretical model by Klein et al. (2003a), where job flows are put in relation with industry-specific real exchange rate (RER) changes and openness to trade. The main prediction of the model is that a real appreciation induces lower job creation and higher job destruction at the industry level, and these effects are stronger the higher is the level of trade exposure in the industry. The main findings of my analysis can be summarized as follows. First, I find that real appreciations do have a negative impact on net employment growth, and this impact increases with the level of trade exposure. Second, concerning the margin of adjustment, the net employment effect is driven by an increase in job destruction, while job creation is not significantly affected. This result is robust to using different measures of job flows, and is stable across a number of different estimations. Such evidence of a job destruction-driven adjustment is in line with earlier findings by Klein et al. (2003a) for the US, and differs from what has been found for other European countries, in particular France (Gourinchas 1999) and Germany (Moser et al. 2010), where the adjustment to RER shocks was mainly driven by the job creation margin. Moser et al. (2010) attributed the difference between the US and Germany to the far-stricter employment protection legislation in Germany, which makes firing costly and thus prevents smooth adjustments to shocks through job destruction. The same explanation could be proposed for France, where employment protection is also high. And yet, according to the OECD Index for the Strictness of Employment Protection, the Belgian labor market displays a level of rigidity in line with Germany and France, and thus much higher than the US one (OECD 2004). ${ }^{5}$ Hence, differences in labor market institutions are not likely to explain the different findings for Belgium on one hand, and France and Germany on the other. In my interpretation, these different findings are consistent with Belgium being a small open economy. Indeed, Belgian firms are operating in a much smaller domestic market than French or German firms, and they face, on average, much higher levels of trade exposure. As a result, they are forced to be more reactive to shocks hitting their international competitiveness. This may explain why Belgian firms adjust through the job destruction margin when they face a real exchange rate shock. In fact, even though destroying jobs can be costly for the firms, due to the strictness of employment protection, the cost of failing to adjust timely to the shock may be even higher in a small open economy. Overall, this highlights the importance of studying the effects of RER changes on job flows in different contexts, where results can be significantly different. Analyzing the case of a small open economy constitutes the main contribution of this study.

As previously mentioned, this paper builds upon previous work by Gourinchas (1988, 1999), Klein et al. (2003a) and Moser et al. (2010). More generally, it is related to the growing body of literature on the connections between international trade and the labor market, as reviewed by Klein et al. (2003b) and Crino' (2009). Several studies have explored the impact of increasing foreign competition on net employment growth at the industry level. Net job losses have been found to be

\footnotetext{
5 For instance, the OECD Overall Index for the Strictness of Employment Protection, in 2002, is equal to 3.05 for France, 2.18 for Belgium and 2.09 for Germany. The US value, 0.21, is the lowest among the 28 industrialized countries covered by the sample. The highest level of strictness is instead recorded in Turkey: 3.72 .
} 
induced by lower import prices and RER appreciations in open industrialized economies. ${ }^{6}$ More recently, other papers have started to study the implications of trade also on gross job creation and destruction flows. ${ }^{7}$ Focusing on gross flows is important for assessing the adjustment costs implied by increasing trade integration, as resources get reallocated to their most productive uses. Indeed, trade-related adjustment costs are likely to be proportional to gross flows rather than net ones. Moreover, the same net variation in employment might be generated by different combinations of job creation and job destruction, with potentially diverse welfare implications, as discussed by Klein et al. (2003a, b). ${ }^{8}$ Consistently, this paper focuses on the impact of RER movements both on net and on gross job flows.

My analysis starts in Sect. 2.1 with the computation of job flows, following the methodology developed by Davis and Haltiwanger (1992). In Sect. 2.2, I turn to the analysis of trade exposure at the industry level. In Sect. 2.3, I discuss the computation of real effective exchange rates, following the approach by Gourinchas $(1998,1999)$ and Klein et al. (2003a). In Sect. 3, I present a descriptive analysis of the correlations between job flows, trade exposure and RER movements. In Sect. 4, I first sketch the theoretical model by Klein et al. (2003a), focusing on its main predictions; then, I present the econometric analysis, and discuss the results. Finally, Sect. 5 concludes.

\section{Job flows, trade exposure and real exchange rates}

\subsection{Firm level data and job reallocation analysis}

The job reallocation analysis relies on firm level data for 14,599 Belgian companies, operating over the time span 1996-2002, in 82 NACE 3-digit manufacturing industries. ${ }^{9}$ Data are drawn from the Amadeus database of the Bureau Van Dijk, a Belgian consultancy company. For all firms in the sample, the database provides comprehensive company accounts, including the full time equivalent number of employees, on a yearly basis. On average, firms in the sample account for $66 \%$ of total

\footnotetext{
6 See Branson and Love (1988) and Revenga (1992) for the US, and Burgess and Knetter (1998) for a broader set of countries.

7 Such an evolution is consistent with the recent development of trade models with heterogeneous firms (Melitz 2003; Bernard et al. 2003, to quote the earliest contributions). Indeed, these models suggest that heterogeneous firms within the same industry are likely to be affected differently by trade liberalization. This is likely to generate an intra-industry job reallocation which can be appropriately captured only by studying gross job flows at the industry level. The first empirical contributions by Levinsohn (1999) and Konings et al. (2003) have pointed at higher trade integration as a driver of increasing gross flows, and thus higher turbulence on the job market.

${ }^{8}$ In particular, an increase in job destruction is likely to involve permanent dislocation of high-wage and older workers, which is likely to lead to higher structural unemployment (Davis et al. 1996). Instead, a decrease in job creation is likely to slow the accumulation of human capital, through an increase in the duration of unemployment. Based on such arguments, Klein et al. (2003a, b) argue that the welfare costs of a decrease in job creation may be economically less significant than those of an equivalent increase in job destruction.

9 A total of 103 manufacturing industries are active in Belgium, hence my data cover $80 \%$ of them. See Table 10 in the "Appendix" for a description of the industries, and the number of sample firms per industry. The "Appendix" provides also additional descriptive information on the data set.
} 
official manufacturing employment (see Table 11 in the "Appendix"). The panel is unbalanced, as some firms enter the sample during the considered period, while others exit. For the purposes of my analysis, the year in which the first observation is recorded denotes a firm's entry, while exit is assumed to take place in the year after which no new information is available in the data set. ${ }^{10}$ And yet, a firm's entry in the data set does not necessarily coincide with its market entry, and a firm's exit from the data set does not necessarily correspond to its exit from the market. This implies that entry and exit can only be measured with an error. This shortcoming of Amadeus has been already discussed by previous studies, for instance Gómez-Salvador et al. (2004). In light of this, as a robustness check, the analysis will be performed both on "standard" measures of job flows, and on what will be referred to as "cont" job flows, i.e., job flow figures based on continuing firms only. The latter figures are computed by excluding, in each year, the contribution of entering and exiting firms to job creation and job destruction, in line with Gómez-Salvador et al. (2004). ${ }^{11}$

For the job flows analysis I adopt the same methodology as in Davis and Haltiwanger (1992), which has been extensively employed in the literature. As a first step, employment growth rates $\left(g_{f t}\right)$ at the firm level are computed as the difference in the number of jobs reported by the firm between year $t$ and $t-1$, over the average firm employment in years $t$ and $t-1$ :

$$
g_{f(t)}=\frac{j o b s_{f(t)}-j o b s_{f(t-1)}}{x_{f(t)}}
$$

where $f$ denotes the firm, and $x_{f(t)}=\frac{\left(j o b s_{f(t)}+j o b s_{f(t-1)}\right)}{2} \cdot{ }^{12}$

Then, the job creation rate for industry $i$ at time $t$ is obtained as the weighted summation of all the positive firm growth rates at time $t$ :

$$
\text { Job Creation }_{i(t)}=\sum_{f \in S_{i(t)}^{+}} \omega_{f i(t)} * g_{f(t)}
$$

where $S_{i(t)}^{+}$denotes the subset of firms in industry $i$ witnessing a positive employment growth at time $t$, and the weights $\left(\omega_{f i(t)}\right)$ are defined as the ratio of each firm's employment over total employment in the industry: ${ }^{13}$

$$
\omega_{f i(t)}=\frac{x_{f(t)}}{\sum_{f \in i} x_{f(t)}}
$$

The "standard" measure of job creation in Eq. 2 can be split in two components: (1) job creation "cont", that is accounted for by continuing firms only, and (2) job creation due to entry. Such a split is reported in the job reallocation tables.

\footnotetext{
10 The resulting entry and exit rates are reported in Table 14 in the "Appendix".

11 For each year $t$, continuing firms are those that are active both in $t$ - 1 and $t$, so they do not enter nor exit in $t$.

12 Such a defined employment growth rate is equal to 2 for an entering firm and ( -2$)$ for an exiting one, in the year in which entry/exit takes place.

13 Depending on the scope of the analysis, weights can also be computed at a more aggregated level, e.g., the total sample or groups of industries.
} 
The job destruction rate for industry $i$ at time $t$ is obtained as the weighted summation of all the negative firm growth rates at time $t$, in absolute levels:

$$
\text { Job Destruction }_{i(t)}=\sum_{f \in S_{i(t)}^{-}} \omega_{f i(t)} *\left|g_{f(t)}\right|
$$

where $S_{i(t)}^{-}$denotes the subset of firms in industry $i$ witnessing a negative employment growth at time $t$, and the weights $\left(\omega_{f i(t)}\right)$ are defined as above.

As for job creation, also job destruction in Eq. 4 can be split in two components: (1) job destruction "cont", that is accounted for by continuing firms only, and (2) job destruction due to exit. The split is reported in the job reallocation tables.

The net employment growth rate (net flow) is obtained as the difference between job creation and job destruction:

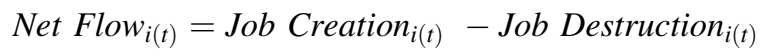

Instead, by summing job creation and job destruction one obtains the gross job reallocation figure (gross flow):

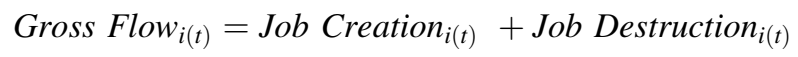

Finally, the excess flow can be obtained by subtracting the net flow, in absolute value, from the gross flow:

$$
\text { Excess Flow }_{i(t)}=\text { Gross Flow }_{i(t)}-\mid \text { Net Flow }_{i(t)} \mid
$$

This is a measure of the job flows exceeding the amount that would be needed in order to just accommodate the net employment change. ${ }^{14}$

Table 1 shows the results of the job reallocation analysis on the pooled sample of 14,599 Belgian firms. Contemporaneous creation and destruction of jobs is documented in each year. On average, the job creation rate is $6.3 \%$, while the destruction one is $4.5 \%$. Positive net flows are observed in all years but in 2002 . The average gross flow is $10.8 \%$, meaning that, on average, around one job out of ten is either created or destroyed in the manufacturing sector every year. This magnitude of turbulence is not negligible, and is in line with earlier findings for Belgium and other European countries by Gómez-Salvador et al. (2004). ${ }^{15}$ However it is significantly lower than what has been documented for the US (20\%) by Davis and Haltiwanger (1992). This difference is commonly attributed to the higher level of rigidity which characterizes the European labor markets (Gómez-Salvador et al. 2004; OECD 2004). Job creation due to the entry of new firms accounts on average for $22 \%$ of the total creation $(1.4$ over $6.3 \%)$. Instead, job destruction due to firm exit accounts for only about $9 \%$ of total destruction $(0.4$ over $4.5 \%)$. The latter low

\footnotetext{
14 Also Net Flow i(t) , Gross Flow ${ }_{i(t)}$ and Excess Flow i(t can be computed in the "cont" version, by employing job creation "cont" and job destruction "cont". They are also reported in the job reallocation tables.

15 In particular, using Amadeus data, and focusing only on continuing firms, Gómez-Salvador et al. (2004) report an average job creation of $5.2 \%$ and an average job destruction of $3.8 \%$ for Belgium. Reassuringly, despite some differences in the samples (in terms of time span and coverage), the latter average figures are very close to what I find for job creation "cont" $(4.9 \%)$ and job destruction "cont" (4.1\%).
} 
Table 1 Job reallocation rates based the whole sample (14,599 firms)

\begin{tabular}{llllllll}
\hline Job flow & 1997 & 1998 & 1999 & 2000 & 2001 & 2002 & Mean \\
\hline Job creation & 0.058 & 0.068 & 0.068 & 0.074 & 0.066 & 0.044 & 0.063 \\
Job destruction & 0.043 & 0.044 & 0.049 & 0.036 & 0.039 & 0.059 & 0.045 \\
Net flows & 0.015 & 0.024 & 0.018 & 0.038 & 0.027 & -0.015 & 0.018 \\
Gross flows & 0.102 & 0.112 & 0.117 & 0.110 & 0.105 & 0.102 & 0.108 \\
Excess flows & 0.087 & 0.088 & 0.099 & 0.072 & 0.078 & 0.087 & 0.085 \\
Job creation "cont" & 0.045 & 0.055 & 0.045 & 0.058 & 0.056 & 0.036 & 0.049 \\
Job creation due to entry & 0.013 & 0.013 & 0.022 & 0.016 & 0.010 & 0.008 & 0.014 \\
Job destruction "cont" & 0.040 & 0.041 & 0.045 & 0.033 & 0.035 & 0.052 & 0.041 \\
Job destruction due to exit & 0.004 & 0.003 & 0.005 & 0.003 & 0.004 & 0.006 & 0.004 \\
Net flows "cont" & 0.005 & 0.014 & 0.001 & 0.025 & 0.020 & -0.017 & 0.008 \\
Gross flows "cont" & 0.084 & 0.096 & 0.090 & 0.091 & 0.091 & 0.088 & 0.090 \\
Excess flows "cont" & 0.079 & 0.082 & 0.089 & 0.066 & 0.070 & 0.072 & 0.076 \\
\hline "Con" fgur rer & & & & & & & .Job
\end{tabular}

"Cont" figures refer to continuing firms only. Job creation figures can be obtained as the sum of "Job creation cont" and "Job creation due to entry". Analogously, job destruction figures can be obtained as the sum of "Job destruction cont" and "Job destruction due to exit"

figure is not surprising, considering that the average size of exiting firms is only 4.3 employees, against a mean size of 15.5 for entering firms, and 32 for the whole sample (see Table 13 in the "Appendix"). ${ }^{16}$

Table 15 in the "Appendix" reports the average ("standard") job flows for each NACE 3-digit industry separately. ${ }^{17}$ All industries display both job creation and job destruction, on average over the time span. The magnitude of job flows is generally considerable. For instance, both creation and destruction rates are lower than $1 \%$ in only about $5 \%$ of the yearly observations. Finally, Table 2 shows a set of summary statistics referring to all industry-specific average job flows. The standard deviations indicate the presence of substantial heterogeneity across industries.

\subsection{Trade exposure}

This section analyzes the trade exposure of the Belgian manufacturing sector, at the 3-digit industry level, over the time span 1996-2002. Three different indexes of trade exposure are employed: (1) overall openness, (2) import competition and (3) export intensity. The overall openness index is computed as the sum of imports and exports over the sum of domestic production and imports, for each 3-digit industry. The import competition index is defined as in Davis et al. (1996): imports over the sum of domestic production and imports; analogously, the export intensity index is given by the ratio of exports over the same denominator.

\footnotetext{
${ }^{16}$ As additional descriptive evidence, Table 12 in the "Appendix" reports the average job flow rates for size-based groups of firms. Consistent with previous studies (e.g., Gómez-Salvador et al. 2004), I find that gross flows decrease monotonically with size.

17 The average number of firms per industry is 178, with a minimum of 5 (NACE 335: manufacture of "watches and clocks") and a maximum of 1,735 (NACE 158: "other food products"). See Table 10 for further details.
} 
Table 2 Summary statistics for industry-specific average job flow rates

\begin{tabular}{llllrr}
\hline Job flow & Obs. & Mean & SD & Min & Max \\
\hline Job creation & 82 & 0.069 & 0.033 & 0.005 & 0.173 \\
Job destruction & 82 & 0.049 & 0.020 & 0.018 & 0.123 \\
Net flows & 82 & 0.020 & 0.038 & -0.062 & 0.130 \\
Gross flows & 82 & 0.118 & 0.040 & 0.037 & 0.271 \\
Excess flows & 82 & 0.067 & 0.028 & 0.010 & 0.156 \\
Job creation "cont" & 82 & 0.052 & 0.019 & 0.005 & 0.111 \\
Job creation due to entry & 82 & 0.017 & 0.022 & 0.000 & 0.119 \\
Job destruction "cont" & 82 & 0.044 & 0.018 & 0.017 & 0.116 \\
Job destruction due to exit & 82 & 0.005 & 0.006 & 0.000 & 0.038 \\
Net flows "cont" & 82 & 0.008 & 0.027 & -0.066 & 0.063 \\
Gross flows "cont" & 82 & 0.096 & 0.025 & 0.037 & 0.178 \\
Excess flows "cont" & 82 & 0.057 & 0.022 & 0.010 & 0.114 \\
\hline "Cont" figures refer to conting
\end{tabular}

"Cont" figures refer to continuing firms only. Job creation figures can be obtained as the sum of "Job creation cont" and "Job creation due to entry". Analogously, job destruction figures can be obtained as the sum of "job destruction cont" and "job destruction due to exit"

For the computation of the indexes, I employ data sourced from the National Bank of Belgium (NBB). These data are based on the Eurostat Prodcom and Comext databases, for domestic production and trade figures, respectively. In both cases, industry level figures have been computed by the NBB starting from the Eurostat product level data, by mapping the product codes into the 3-digit industry codes of the NACE (Rev. 1.1) classification of economic activities.

The overall openness index averages 1.10, ranging from a minimum level of 0.42 to a maximum of 1.92. The import competition and the export intensity indexes average, instead, 0.53 and 0.57 , respectively. Such figures are broadly consistent with the aggregate values of the trade(in goods)-to-GDP ratio provided by the OECD for Belgium: 1.13 in 1996, increasing up to 1.30 in 2002. The same index, in 2002, takes value 0.42 for France, 0.54 for Germany and 0.18 for the US. Overall, the 3-digit figures confirm, at a more disaggregated level, that Belgian firms face very high levels of trade exposure, which are typical of a small open economy.

In order to investigate the cross-industry variation in trade exposure more in depth, Fig. 1 shows the evolution of the overall openness index at the 10th, 25th, 50th 75th and 90th percentiles of the index distribution across the 82 3-digit industries. The graph confirms a trend of increasing openness over the time span. For instance, the median value of the index grows from 1.07 up to 1.15 . In addition to that, there is evidence of considerable and increasing heterogeneity in openness across industries. Indeed, the distance between the 10th-25th and 90th percentiles is high at the beginning of the sample and increases over time, as the growth in trade openness for the more open industries is not matched by analogous dynamics for the relatively closed ones. ${ }^{18}$

\footnotetext{
18 A similar trend is also found both for the import competition index and for the export intensity index, separately considered.
} 


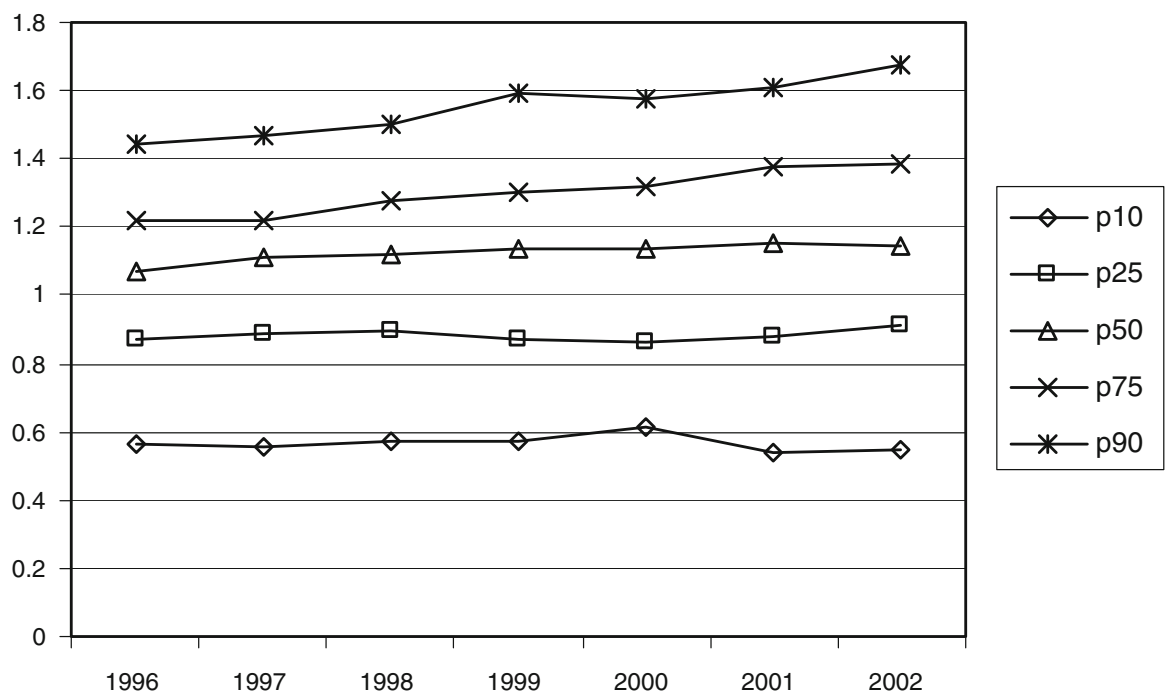

Fig. 1 Overall openness index: percentiles evolution

\subsection{Real exchange rates}

In theory, the real exchange rate is defined as the following ratio: the price of domestic goods over the price of foreign goods sold by the trading partners, both expressed in domestic currency. For the computation of industry-specific RER movements, I follow the same methodology as in Gourinchas $(1998,1999)$ and Klein et al. (2003a), which is based on the Wholesale Price Index (WPI). However, while they take into account only the major trading partners of each industry, I compute the real exchange rates with respect to a set of 73 foreign countries, which account, on average, for at least $95 \%$ of total trade in each 3-digit industry. This is meant to improve the level of accuracy with respect to the above-mentioned studies. In fact, focusing only on the major trading partners, as in their approach, may lead to disregarding countries that account for up to $50 \%$ of trade in each industry. ${ }^{19}$ Recently, Moser et al. (2010) have employed an alternative measure of RER, which is based on the cross-country comparison of the average hourly wages, all denominated in the same currency. The main advantage of such an approach is that of focusing explicitly on labor costs, which are likely to be most relevant when studying firms' employment decisions. The shortcoming, though, is that other factors' costs and differences in productivity dynamics across countries are not

19 In particular, in Gourinchas (1998) “country $i$ is considered a major trading partner for industry $j$ if either (1) country $i$ is among the largest trading partners accounting for the first $50 \%$ of exports/imports for industry $j$ or (2) trade with country $i$ represents more than $10 \%$ of exports/imports, on average over the sample period". The same definition is then adopted in Gourinchas (1999) and Klein et al. (2003a). 
taken into account. ${ }^{20}$ A WPI-based measure of RER is supposed to be more comprehensive in this respect, as discussed by Gourinchas (1998). ${ }^{21}$

For computing the industry-specific RER movements I proceed as follows. As a first step, I obtain the series of bilateral real exchange rates for Belgium with respect to each trading partner $j$, in each year $t$, as follows:

$$
E_{j(t)}=\frac{W P I_{B e l g i u m}(t)}{N E R_{j(t)} * W P I_{j(t)}}
$$

where $N E R_{j(t)}$ is the bilateral nominal exchange rate, and WPI denotes the Wholesale Price Index. Data are sourced from the International Financial Statistics database (IFS) provided by the IMF. ${ }^{22}$

As an outcome of this first step, for every year I obtain a series of RER percentage variations with respect to each of the trading partners $\left(\Delta E_{j(t)}\right)$. Building on this, I then compute the change in each industry-specific RER $\left(\Delta E_{i(t)}\right)$ as a weighted summation of the bilateral RER percentage variations $\left(\Delta E_{j(t)}\right)$. I employ as weights the industry-specific trade shares of each trading partner. In particular, in order to smooth the series and avoid endogeneity problems in the econometric analysis, a lagged two years moving average of shares is adopted. In formulas:

$$
\Delta E_{i(t)}=\sum_{j=1}^{73} \omega_{j(t)}^{i} * \Delta E_{j(t)}
$$

where, as in Klein et al. (2003a), the weight of trading partner $j$, at time $t$, for industry $i$ is defined as follows:

$$
\omega_{j(t)}^{i}=\left(\frac{1}{2}\right) \sum_{s=1}^{2}\left[\frac{X_{i j(t-s)}+M_{i j(t-s)}}{\sum_{j=1}^{73}\left(X_{i j(t-s)}+M_{i j(t-s)}\right)}\right]
$$

where $X_{i j}$ and $M_{i j}$ stand for industry-specific exports and imports to/from country $j$, respectively.

A positive $\Delta E_{i(t)}$ constitutes a real appreciation. Conversely, a negative $\Delta E_{i(t)}$ indicates a real depreciation, with domestic goods becoming more competitive as compared to foreign ones. Since the 82 3-digit industries are characterized by different trade patterns, i.e., they trade more/less intensively with different trading partners, I find extensive cross-industry heterogeneity in RER movements. In particular, given the unique set of bilateral RER variations in each year $\left(\Delta E_{j(t)}\right.$ in

\footnotetext{
20 This disadvantage of the wage-based measure of RER is openly discussed by Moser et al. (2010). Indeed, as a robustness check they also enrich their analysis by employing a RER measure based on a capital goods price index.

21 Moreover, comparable labor cost indicators would only be available for about half of the 73 trading partners considered in the analysis (from the OECD System of Unit Labor Cost Indicators). Lack of crosscountry data is also the reason why the aggregate WPI index is used, rather than disaggregated industryspecific indicators, which would be available for Belgium and the other EU countries.

22 For some of the trading partners, WPI data were not available in the IFS database. In such cases, WPI data have been retrieved from the national statistical offices. This has been the case for France, Luxembourg, Portugal, Malta, Turkey, China, Taiwan, Russia and Ukraine.
} 


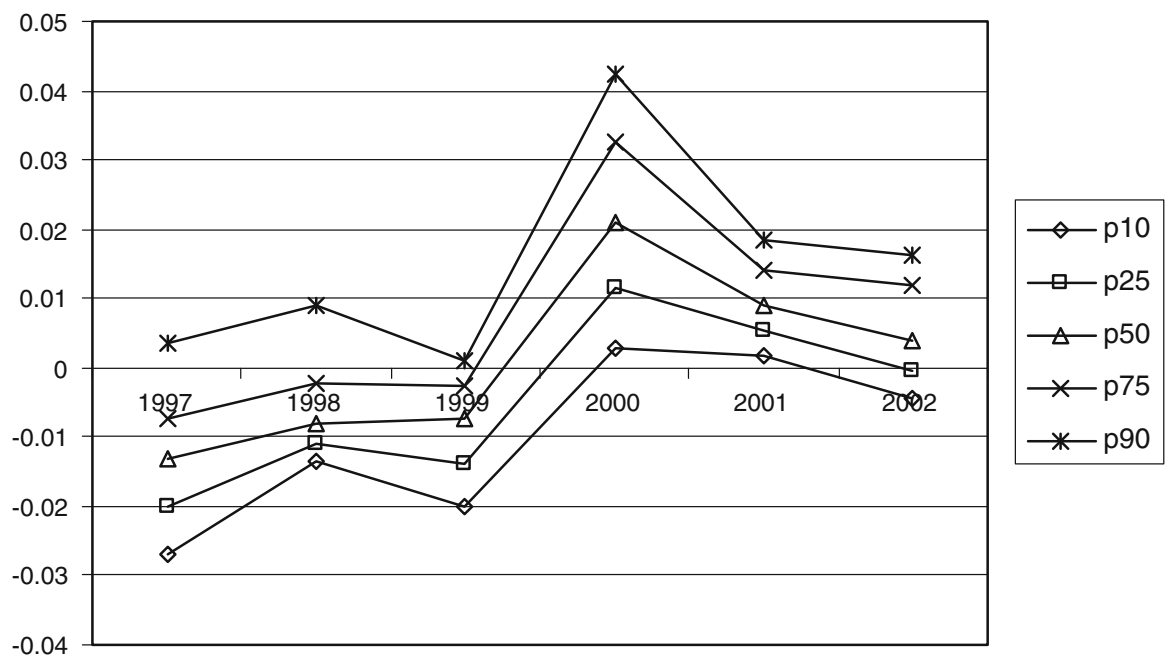

Fig. 2 Real effective exchange rates: percentiles of growth rates

Eq. 8) some industries experience a real depreciation, while others face a real appreciation at the same time, due to differences in the composition of trade (i.e., the trade shares $\omega_{j(t)}^{i}$ in Eq. 8). The heterogeneity in RER movements across industries is illustrated in Fig. 2. In particular, for each year, the 10th, 25th, 50th, 75th and 90th percentiles of the $\Delta E_{i(t)}$ distribution are displayed. The diversity in RER dynamics, together with the analyzed heterogeneity in trade exposure, is expected to be relevant in explaining the cross-industry variation of job flows. In the following sections, the relation between real effective exchange rates, trade exposure and job flows dynamics is investigated, both at the descriptive and the econometric level.

\section{Job flows and international factors: descriptive evidence}

In this section, raw correlations between job flows and international competition factors are explored at the descriptive level. In particular, in the spirit of previous studies by Levinsohn (1999) and Konings et al. (2003), job flow rates are compared across homogeneous groups of industries, based on average trade exposure and RER movements. The starting point for this analysis is thus the computation of industryspecific average figures for the following indexes: overall openness, import competition, export intensity and the change in the industry-specific RER. Based on the obtained average values, the 82 industries are aggregated into six different groups with respect to each of the four heterogeneity dimensions, each considered separately from the others. Cut-off values are the 10th, 25th, 50th, 75th and 90th percentiles of the cross-industry distributions of the four relevant indexes. The job reallocation analysis is then performed for each of the resulting 24 groups of 


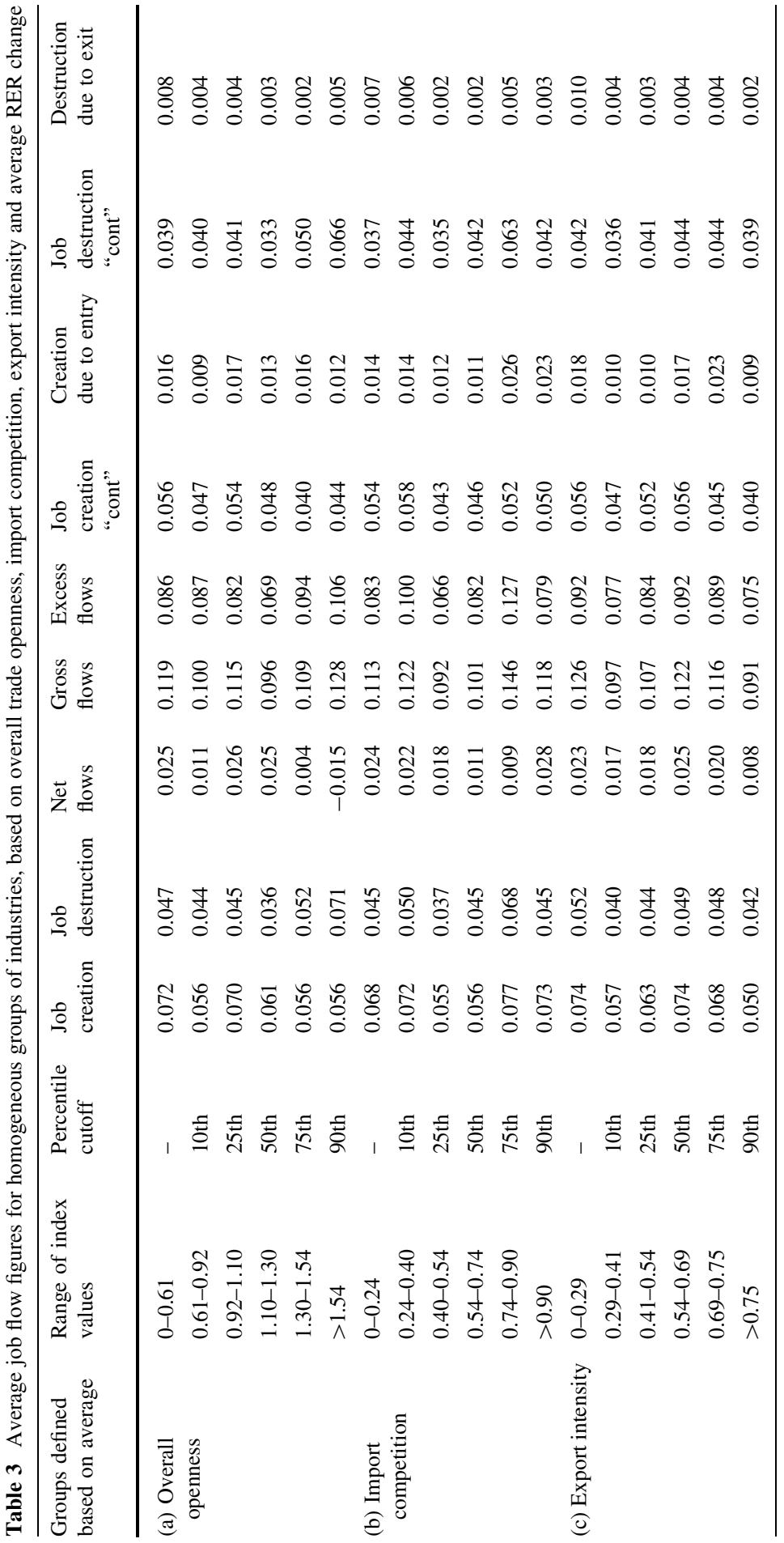




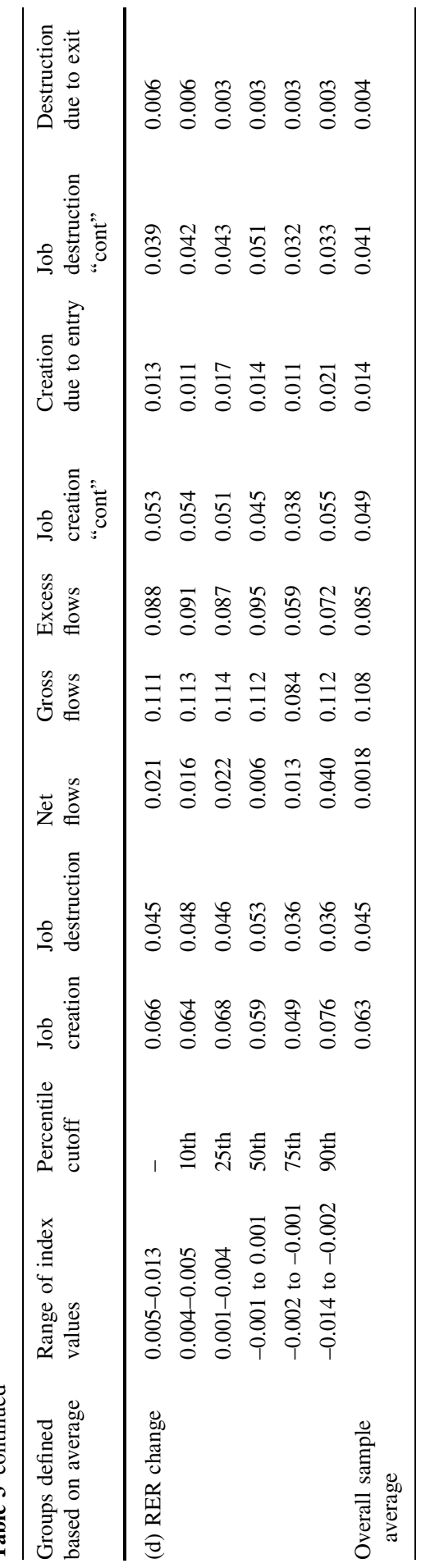


industries (i.e., 6 groups $* 4$ heterogeneity dimensions), and average job flows are computed.

Panel (a) of Table 3 shows the results for the 6 groups of industries based on the average levels of overall openness to trade. When looking at the figures for the two most open groups, higher trade exposure seems to be associated with somewhat higher job destruction and lower net flows. Gross flows are also greater than the average for the most open industries.

In panels (b) and (c) the correlations with respect to import competition and export intensity are separately explored. Groups of industries characterized by higher levels of import competition display above average gross flows, resulting both from higher job creation and higher job destruction. Instead, average job flows do not display any evident correlation with respect to export intensity levels.

The results for industry groups based on RER movements are reported in panel d). The last group contains those industries experiencing the most favorable exchange rate variations, i.e., the largest average depreciations over the time span. The corresponding job flow figures seem to suggest that real depreciations are associated with higher than average net employment growth, resulting both from higher job creation and from lower job destruction.

Overall, these results need to be evaluated carefully. The one just discussed is indeed only a preliminary and descriptive analysis. Differences in job flows across groups are generally small, and could be determined by different factors than the ones explored. In the next section, the relation between job flows and international competition factors is further investigated through econometric analysis.

\section{Econometric analysis}

\subsection{Theoretical background}

Before presenting the econometric analysis, this section reviews the main elements and the predictions of the model by Klein et al. (2003a), which constitutes the theoretical background of the analysis.

In a context of openness to trade, international factors are modeled as affecting the demand equation for each firm's output as follows:

$$
Q_{p}=A_{p} Y^{\beta} \Pi_{j=1}^{k}\left[E_{j}^{-\mu \Omega_{i}} Y_{j}^{* \beta \Omega_{i}}\right]^{\omega j_{j}^{i}}
$$

where $Q_{p}$ is the demand for the output of firm $p$ in industry $i$, and $A_{p}$ is the idiosyncratic demand shock faced by the same firm. Since output can be sold both domestically and abroad, the demand equation includes both $Y$, a measure of domestic income, and a multiplicative expression capturing foreign demand. Each term of the latter expression refers to a single country $j$ and is influenced by several factors. In particular, the demand contribution of each foreign country is directly proportional to its income $Y_{j}^{*}$, and inversely related to the bilateral RER $E_{j}$. The latter is in fact defined as the ratio of the price of domestic goods over the price of foreign goods (in domestic currency), as explained in Sect. 2.3. Thus, the higher 
$E_{j}$, the lower the competitiveness of firm $p$ output. The impact of $Y_{j}^{*}$ and $E_{j}$ is directly proportional to $\Omega_{i}$, an indicator for the level of trade openness of the industry, which does not vary across firms. ${ }^{23}$ Finally, the contribution of each trading partner is weighted by its share in the total trade of the industry, $\omega_{j}^{i}$, which is also common to all firms within the same industry. ${ }^{24}$

Labor demand growth at the firm level has the following expression:

$$
\widehat{L_{p}}=-(1-\alpha) \widehat{W_{p}}+(1-\alpha) \widehat{G_{p}}+\widehat{A_{p}}+\beta \widehat{Y}-\mu \Omega_{i} \widehat{E}_{i}+\beta \Omega_{i} \widehat{Y_{i}^{*}}
$$

where the notation $\widehat{Z}$ stands for $d \ln (Z)$, for any variable $Z$. The variable $W_{p}$ is the wage and the variable $G_{p}$ is the unit-cost of the non-labor input. The term $\widehat{E}_{i}$ is the industryspecific, trade-weighted RER variation. Analogously, $\widehat{Y_{i}^{*}}$ is the trade-weighted growth of foreign partners' output. ${ }^{25}$ Taking into account the general equilibrium effects of RER movements on wages (disregarding for simplicity variations in $G, Y$ and $Y^{*}$ ), the final expression for firm level labor demand growth is as follows:

$$
\widehat{L_{p}}=\left(\widehat{A_{p}}-k \widehat{A_{i}}\right)-k \varepsilon \gamma \widehat{\Gamma}-(1+k) \mu \Omega_{i} \widehat{E_{i}}
$$

where $A_{i}$ is an industry-specific idiosyncratic shock, resulting from the summation of the firm-specific ones. The variable $k$ is a parameter ranging between zero and one, $\gamma$ is a measure of labor supply elasticity $(\gamma>0), \varepsilon$ is the cross-elasticity of labor supply between industry $i$ and the rest of the economy $(\varepsilon \geq 0)$, and $\Gamma$ is the prevailing wage in the rest of the economy.

Equation 12 implies that, ceteris paribus, a real appreciation $\left(\widehat{E}_{i}>0\right)$ has a negative effect on labor demand at the firm level, and this effect is magnified by increasing levels of trade openness $\left(\Omega_{i}\right)$. Since industry-specific job flows are computed as weighted summations of the firm-specific ones, the final prediction of the model is that a real appreciation, ceteris paribus, induces lower job creation and higher job destruction at the industry level. These effects are stronger the higher the level of trade exposure in the industry. The intuition for this is straightforward: higher exposure to trade implies enhanced sensitivity to international competitive factors. ${ }^{26}$

\footnotetext{
${ }^{23}$ The indicator $\Omega_{i}$ is defined at the industry level as the following ratio: (imports + exports)/(domestic production + imports).

24 This feature of the model matches the characteristics of my data. Indeed, I do not observe firm-specific trade exposure and trading partners' shares.

25 In formulas, they are defined as follows: $\widehat{E}_{i}=\sum_{j=1}^{J_{i}} \omega_{j}^{i} \widehat{E}_{j} ; \widehat{Y_{i}^{*}}=\sum_{j=1}^{J_{i}} \omega_{j}^{i} \widehat{Y_{j}^{*}}$, where $J_{i}$ is the total number of trading partners of industry $i$.

26 As an effect of the firm-specific idiosyncratic shocks $\left(A_{p}\right)$, the model allows for contemporaneous creation and destruction of jobs across different firms within the same industry. This property of the model fits a well documented empirical regularity. While this outcome in the model is just a result of idiosyncratic shocks, a recent stream of literature on heterogeneous firms has identified a number of factors which can systematically determine it. For instance, different firms may display diversified reactions to international trade shocks, depending upon heterogeneous productivity levels (Melitz 2003; Bernard et al. 2003), capital intensity and product-mix (Bernard et al. 2006; Khandelwal 2010). Moreover, firms within the same industry are likely to face heterogeneous levels of trade exposure, as documented, among others, by Bernard et al. (2007a), Mayer and Ottaviano (2007) and Moser et al. (2010)
} 


\subsection{Empirical strategy}

Drawing on the presented theoretical framework by Klein et al. (2003a), and building upon previous work by Moser et al. (2010), the baseline estimation equation for the econometric analysis is specified as follows:

$$
\begin{aligned}
\text { Job_Flow }_{i(t)}= & \alpha_{0}+\alpha_{1} \text { Job_Creation }_{i(t-1)}+\alpha_{2} J_{\text {Job_Destruction }}(t-1) \\
& +\alpha_{3}\left(\text { Openness_Index }_{i(t)} * \Delta E_{i(t)}\right)+\alpha_{4} Z_{i(t)}+\alpha_{5} X_{(t)}+\alpha_{i}+\varepsilon_{i(t)}
\end{aligned}
$$

where $i$ refers to 3-digit industries and $t$ indexes years. The term $\mathbf{Z}_{i(t)}$ is a vector of industry-specific control variables, while $\mathbf{X}_{(t)}$ is a vector of macro-controls, which do not vary across industries. $\boldsymbol{\alpha}_{i}$ is a vector of 3 -digit industry fixed effects, and $\varepsilon_{i(t)}$ is the estimation error.

The dependent variable $J o b \_F l o w_{i(t)}$ corresponds to, alternatively, one of the following four job flows: Net_Flow ${ }_{i(t)}$, Job_Creation ${ }_{i(t)}$,Job_Destruction $_{i(t)}$, and Gross_Flowi(t). The lagged values of job creation and job destruction are always included as regressors, in order to account for possible dynamic adjustments.

Openness_Index $_{i(t)} * \Delta E_{i(t)}$ stands for the interaction between the change in the industry-specific RER $\left(\Delta E_{i(t)}\right)$ and the overall trade openness index at the industry level (Openness_Index ${ }_{i(t)}$ ). This interaction variable is crucial with respect to the research question, and its inclusion follows directly from the theoretical framework presented in Sect. 4.1. The term $\Delta E_{i(t)}$ is computed as in Eq. 8, i.e., as a tradeweighted average of bilateral RER changes with respect to a set of 73 trading partners. Openness_Index $x_{i(t)}$ is instead obtained as explained in Sect. 2.2, as the sum of imports and exports over the sum of domestic production and imports, for each 3digit industry. In particular, a lagged two-year moving average of this ratio is employed, in order to avoid endogeneity problems in the estimation. In addition, I will also present regressions in which $\Delta E_{i(t)}$ is interacted with the alternative measures of trade exposure: the import competition index and the export intensity index, both computed as explained in Sect. 2.2. and both employed as lagged twoyear moving averages.

The set of industry controls, $\mathbf{Z}_{i(t)}$, contains the following variables:

$$
\left[\begin{array}{c}
\text { Openness_Index } x_{i(t)} * \Delta Y_{i(t)}^{*}, R C A_{i(t)}, \text { Herfindahl_Index } \\
\text { Relative_price_change } e_{i(t-1)}, \text { Mean_tangible_assets } s_{i(t-1)}
\end{array}\right]
$$

Openness_Index $_{i(t)} * \Delta Y_{i(t)}^{*}$ is the interaction between the openness index, constructed as above, and $\Delta Y_{i(t)}^{*}$, which represents the industry-specific average percentage change in the real GDP of the trading partners. ${ }^{27}$ The inclusion of this interaction variable is motivated by the theoretical model (see Eq. 11), and is meant

\footnotetext{
27 Alternatively, along with the changes in the $\Delta E_{i(t)}$ interaction, $\Delta Y_{i(t)}^{*}$ will also be interacted with the other indicators of trade exposure: import competition and export intensity.
} 
to capture a second determinant of foreign demand, besides real exchange rates. ${ }^{28}$ $R C A_{i(t)}$ represents an industry-specific measure of revealed comparative advantage. Following the standard definition by Balassa (1965), it is computed as the following ratio:

$$
R C A_{i(t)}=\frac{\frac{\text { Export }_{i(t)}}{\text { Import }_{i(t)}}}{\sum_{i=1}^{n} \text { Export }_{i(t)}}
$$

where $n$ stands for the total number of 3-digit industries (indexed by the subscript $i$ ).

The inclusion of this control follows from recent theoretical results by Bernard et al. (2007b), who have shown that job flows in an industry might be systematically related to the comparative advantage enjoyed by the same industry. In particular, Bernard et al. (2007b) have analyzed, at the theoretical level, the effects of increasing openness to trade on multiple domestic industries, characterized by heterogeneous firms and comparative advantages. Their model predicts that, in the adjustment to increasing trade exposure, comparative disadvantage industries display net job destruction, while comparative advantage ones enjoy net employment growth. However, higher trade exposure triggers simultaneous job creation and destruction in all industries, and this effect tends to be magnified in industries characterized by a relative comparative advantage. In fact, the market selection induced by trade is stronger for comparative advantage industries than for comparative disadvantage ones. The inclusion of $R C A_{i(t)}$ in the empirical model is meant to control for the latter effects.

Several studies have linked job flows with product market imperfections, market concentration and the pricing power of firms within an industry (Geroski et al. 1995; Bertrand and Kramarz 2002; Blanchard and Giavazzi 2003; Peoples 1998; Boeri et al. 2000). In particular, these studies have shown that high market concentration, associated with high markups and barriers to entry, may have a negative impact on employment growth. Following this literature, $\mathbf{Z}_{i(t)}$ includes three additional industry level controls for the market structure: (1) Herfindahl_Index ${ }_{i(t-1)}$, (2) Relative_price_change $_{i(t-1)}$, and (3) Mean_tangible_assets $i_{i(t-1)}$. They are obtained as follows. (1) Herfindahl_Index i(t-1) $_{1}$ is computed using firm level turnover data from the Amadeus sample. In particular, first the market share of each firm is computed, for each year, with respect to the total sample figure of turnover within the corresponding 3-digit industry (i.e., the sum of firm level turnover for each sample firm within the industry). Then, the Herfindahl Index is obtained as the sum of each firm's squared market share, for each industry $i$ and year $t$. (2) Relative_price_change $_{i(t-1)}$ is the relative change in the Producer Price Index (PPI) of industry $i$ with respect to the average figure for the whole manufacturing sector in the same year. For instance, if the PPI in year $t$ increases by $3 \%$ in industry $i$, while the average increase in the manufacturing sector is $1 \%$, the relative price change for

\footnotetext{
${ }^{28}$ The term $\Delta Y_{i(t)}^{*}$ is defined, equivalently to $\Delta E_{i(t)}$, as a trade-weighted summation of each partner's growth rate (see footnote 25). The employed trade shares are the same lagged two-year moving averages used for the computation of $\Delta E_{i(t)}$ (see Eq. 9). The real GDP growth rates of the trading partners are sourced from the IFS database.
} 
industry $i$ will be $2 \%$. The construction of this variable is in line with Klein et al. (2003a), and its computation is based on Eurostat data on PPIs at the 3-digit industry level. (3) Mean_tangible_assets i $t-1)_{1}$ is the average firm level value of tangible fixed assets within each given industry (and year). This variable is meant to control for barriers to entry (Geroski et al. 1995). It is computed based on the Amadeus firm level data, just as the Herfindahl Index, and all the job flow figures employed in the analysis.

The vector of macro-controls, $\mathbf{X}_{(t)}$, contains the following variables:

$$
\left[\begin{array}{c}
\text { Real_interest_rate }_{(t)}, G D P \_ \text {growth_rate }(t), \\
\text { Real_wage_growth_rate }(t)_{(t)}, \text { Tot_employment_growth_rate }(t)
\end{array}\right]
$$

As already anticipated, all these regressors do not vary across industries but only through time, and their inclusion follows earlier work by Klein et al. (2003a) and Moser et al. (2010). These variables are meant to control for aggregate dynamics which could be correlated with real exchange rate movements, thus potentially leading to spurious findings of significant effects of RER changes on job flows.

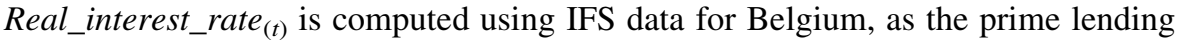
rate minus the inflation rate. GDP_growth_rate $(t)$ is the real GDP growth rate of Belgium, also obtained from IFS. Real_wage_growth_rate $(t)$ is the average growth rate of wages in the manufacturing sector of Belgium, deflated using the Consumer Price Index (CPI). In order to construct this variable, the nominal average growth rate of wages is computed using Amadeus firm level data on total staff costs. In particular, the latter costs are first divided for the number of employees (full time equivalent), as to retrieve the average wage at the firm level in each year. Then, the yearly average is taken across all firms in the sample, and the nominal growth rate is computed over the years. Finally, the nominal figures are deflated using CPI data for Belgium, retrieved from the IFS. Tot_employment_growth_rate $(t)$ stands for the net employment growth for the whole manufacturing sector. As explained in Sect. 2.1, this variable is obtained as the difference between the job creation rate and the job destruction rate, computed over the full sample of 14,599 Belgian companies, using Amadeus data. The resulting figures are presented in the third row of Table 1.

Concerning the econometric methodology, it is important to notice that the specification outlined in Eq. 13 is a dynamic panel model. In fact, depending on the employed dependent variable (Net_Flow ${ }_{i(t)}$, Job_Creation ${ }_{i(t)}$, Job_Destruc- $_{-}$ tion $_{i(t)}$, Gross_Flow $w_{i(t)}$ ), either the dependent variable itself, or its components of job creation and destruction, appear with a 1-period lag among the regressors. As shown by Nickell (1981), if the time dimension of the panel is small, as in my case, a fixed-effects estimator is inconsistent for dynamic models, due to the correlation of the lagged dependent variable with the group-mean of the error term: the socalled "Nickell bias". In particular, as discussed by Moser et al. (2010), when only the first lag of the dependent variable is included as a covariate, a fixed-effects estimator will underestimate the coefficient of the lagged dependent variable. On the other hand, an OLS estimator will have an opposite bias, due to the endogeneity of the lagged dependent variable (Trognon 1978). In order to obtain consistent 
Table 4 Regression results for net flows, with RER changes interacted with the overall openness index

\begin{tabular}{llll}
\hline $\begin{array}{l}\text { Estimation method } \\
\text { Dependent variable } i(t)\end{array}$ & $\begin{array}{l}\text { OLS } \\
\text { Net flows } \\
(1)\end{array}$ & $\begin{array}{l}\text { Fixed effects } \\
\text { Net flows } \\
(2)\end{array}$ & $\begin{array}{l}\text { System- } \\
\text { Net flo } \\
(3)\end{array}$ \\
\hline Job creation $i(t-1)$ & 0.101 & $-0.234 * * *$ & 0.022 \\
Job destruction $i(t-1)$ & {$[0.071]$} & {$[0.074]$} & {$[0.088]$} \\
& -0.146 & 0.221 & -0.052 \\
{$[0.108]$} & {$[0.142]$} & {$[0.124]$}
\end{tabular}

Job creation "cont" $i(t-1)$

$0.432 * * *$

[0.125]

Job destruction "cont" $i(t-1)$

[0.088]

Openness_Index $i(t) *$ AE $i(t)$ $-0.578 * \quad-0.625$

$-0.580 *$

$-0.425 * *$

[0.346]

[0.414]

[0.348]

[0.204]

Openness_Index $i(t) * \mathrm{AY}^{*} i(t)$

0.011

$-0.248$

$-0.102$

0.019

\section{[0.386]}

[0.906]

[0.399]

[0.230]

$\mathrm{RCA} i(t)$

$-0.005$

$-0.003$

$-0.003$

0.001

Herfindahl index $i(t-1)$

[0.007]

[0.019]

[0.006]

[0.005]

$-0.003$

$0.374 * * *$

0.02

$-0.016$

[0.028]

[0.120]

[0.032]

[0.019]

Relative price change $i(t-1)$

0.032

$-0.01$

0.03

$-0.166^{* *}$

$$
\text { [0.189] }
$$

[0.163]

[0.191]

[0.081]

Mean tangible assets $i(t-1)$

$-0.002 * * *$

$-0.006^{*}$

$-0.003 * * *$

$-0.002 * *$

[0.001]

[0.003]

[0.001]

[0.001]

Real interest rate $(t)$

0.052

0.014

0.048

$-0.083$

GDP growth rate (t)

[0.103]

[0.095]

[0.096]

[0.068]

0.762

0.455

0.769

$-1.39$

[1.639]

[1.257]

[1.498]

[1.089]

Real wage growth rate $(t)$

$-0.839$

$-0.781$

$-0.824$

0.896

[1.593]

[1.574]

[1.502]

[1.003]

Tot employment growth rate $(t)$

$\begin{array}{ll}0.821 * * * & 0.689 \\ {[0.309]} & {[0.502]} \\ -0.291 & -0.117 \\ {[0.618]} & {[0.582]} \\ 394 & 394 \\ 0.08 & 0.2\end{array}$

Observations

R-squared

AR1 test ( $p$-value)

AR2 test ( $p$-value)

Hansen test ( $p$-value)
$0.829 * * *$

$0.616^{* *}$

[0.311]

[0.254]

$-0.266$

0.491

[0.575]

[0.407]

394

394

$\begin{array}{ll}0.002 & 0.000 \\ 0.470 & 0.594 \\ 0.433 & 0.447\end{array}$

Standard errors (in parentheses) are clustered within NACE 3-digit industries. In the system-GMM regressions, job creation $i(t-1)$ and job destruction $i(t-1)$, or job creation "cont" $i(t-1)$ and job destruction "cont" $i(t-1)$, are instrumented using a full set of their valid time-lags. The other explanatory variables are treated as exogenous. $* * *, * *, *$ indicate significance at 1,5 and $10 \%$, respectively 
Table 5 Regression results for job creation, with RER changes interacted with the overall openness index

\begin{tabular}{llll}
\hline $\begin{array}{l}\text { Estimation method } \\
\text { Dependent variable } i(t)\end{array}$ & $\begin{array}{l}\text { OLS } \\
\text { Job creation } \\
(1)\end{array}$ & $\begin{array}{l}\text { Fixed effects } \\
\text { Job creation } \\
(2)\end{array}$ & $\begin{array}{l}\text { System- } \\
\text { Job crea } \\
(3)\end{array}$ \\
\hline Job creation $i(t-1)$ & $0.103^{*}$ & $-0.266^{* * *}$ & 0.012 \\
Job destruction $i(t-1)$ & {$[0.060]$} & {$[0.040]$} & {$[0.067]$} \\
& 0.098 & 0.162 & 0.102 \\
& {$[0.090]$} & {$[0.098]$} & {$[0.088]$}
\end{tabular}

Job creation "cont" $i(t-1)$

$0.218^{* * *}$

[0.075]

0.083

[0.061]

Openness_Index $i(t) * \mathrm{AE} i(t)$

-0.147
$[0.236]$

$-0.369$

$-0.191$

$-0.084$

[0.354]

[0.250]

[0.102]

Openness_Index $i(t) * \mathrm{AY}^{*} i(t)$

\subsection{4}

$-0.738$

$-0.046$

0.134

[0.317]

[0.689]

[0.330]

[0.173]

RCA $i(t)$

$-0.009$

0.007

$-0.008$

$-0.003$

[0.007]

[0.014]

Herfindahl index $i(t-1)$

$-0.002$

$0.292 * * *$

[0.007]

[0.002]

[0.023]

[0.105]

0.02

[0.027]

$-0.022 * *$

[0.010]

Relative price change $i(t-1)$

0.117

0.035

0.098

$-0.052$

[0.153]

[0.146]

[0.157]

[0.032]

Mean tangible assets $i(t-1)$

$-0.002 * * * \quad-0.002$

[0.000]

[0.003]

$-0.002 * * *$

$-0.001 * * *$

Real interest rate $(t)$

$0.157^{* *}$

0.051

[0.001]

[0.000]

$0.136^{*}$

0.021

[0.079]

[0.075]

[0.071]

[0.034]

GDP growth rate (t)

$2.428^{*}$

1.331

2.192*

0.231

[1.279]

[0.988]

[1.135]

[0.553]

Real wage growth rate $(t)$

$-2.042 *$

$-0.718$

$-1.757$

$-0.329$

[1.202]

[1.215]

[1.116]

[0.520]

Tot employment growth rate $(t)$

0.349

$0.610^{*}$

$0.393 *$

0.21

[0.232]

[0.344]

[0.232]

[0.157]

Constant

-0.880 *

$-0.284$

$-0.753 *$

$-0.085$

[0.469]

[0.459]

Observations

394

394

[0.423]

394

[0.209]

0.07

0.19

394

AR1 test ( $p$-value)

0.007
0.680
0.310

AR2 test ( $p$-value)

0.310

0.000

0.669

Hansen test ( $p$-value)

0.113

Standard errors (in parentheses) are clustered within NACE 3-digit industries. In the system-GMM regressions, job creation $i(t-1)$ and job destruction $i(t-1)$, or job creation "cont" $i(t-1)$ and job destruction "cont" $i(t-1)$, are instrumented using a full set of their valid time-lags. The other explanatory variables are treated as exogenous. $* * *, * *, *$ indicate significance at 1,5 and $10 \%$, respectively 
Table 6 Regression results for job destruction, with RER changes interacted with the overall openness index

\begin{tabular}{|c|c|c|c|c|}
\hline $\begin{array}{l}\text { Estimation method } \\
\text { Dependent variable } i(t)\end{array}$ & $\begin{array}{l}\text { OLS } \\
\text { Job } \\
\text { destruction } \\
\text { (1) }\end{array}$ & $\begin{array}{l}\text { Fixed effects } \\
\text { Job } \\
\text { destruction } \\
\text { (2) }\end{array}$ & $\begin{array}{l}\text { System-GMM } \\
\text { Job } \\
\text { destruction } \\
\text { (3) }\end{array}$ & $\begin{array}{l}\text { System-GMM } \\
\text { Job destruction } \\
\text { "cont" } \\
\text { (4) }\end{array}$ \\
\hline Job creation $i(t-1)$ & $\begin{array}{l}0.002 \\
{[0.040]}\end{array}$ & $\begin{array}{l}-0.032 \\
{[0.040]}\end{array}$ & $\begin{array}{l}-0.011 \\
{[0.041]}\end{array}$ & \\
\hline Job destruction $i(t-1)$ & $\begin{array}{l}0.244 * * * \\
{[0.053]}\end{array}$ & $\begin{array}{l}-0.06 \\
{[0.053]}\end{array}$ & $0.154 * * *$ & \\
\hline Job creation "cont" $i(t-1)$ & & & & $\begin{array}{l}-0.214 * * * \\
{[0.081]}\end{array}$ \\
\hline Job destruction "cont" $i(t-1)$ & & & & $\begin{array}{l}0.194 * * * \\
{[0.041]}\end{array}$ \\
\hline Openness_Index $i(t) *$ AE $i(t)$ & $\begin{array}{l}0.431 * * \\
{[0.210]}\end{array}$ & $\begin{array}{l}0.255^{*} \\
{[0.148]}\end{array}$ & $\begin{array}{l}0.389 * * \\
{[0.197]}\end{array}$ & $\begin{array}{l}0.341 * * \\
{[0.175]}\end{array}$ \\
\hline Openness_Index $i(t) * \mathrm{AY} * i(t)$ & $\begin{array}{l}0.053 \\
{[0.186]}\end{array}$ & $\begin{array}{l}-0.49 \\
{[0.421]}\end{array}$ & $\begin{array}{l}0.057 \\
{[0.192]}\end{array}$ & $\begin{array}{l}0.115 \\
{[0.172]}\end{array}$ \\
\hline $\mathrm{RCA} i(t)$ & $\begin{array}{l}-0.004 \\
{[0.003]}\end{array}$ & $\begin{array}{l}0.009 \\
{[0.011]}\end{array}$ & $\begin{array}{l}-0.005 \\
{[0.003]}\end{array}$ & $\begin{array}{l}-0.005 \\
{[0.003]}\end{array}$ \\
\hline Herfindahl index $i(t-1)$ & $\begin{array}{l}0.001 \\
{[0.014]}\end{array}$ & $\begin{array}{l}-0.082 \\
{[0.060]}\end{array}$ & $\begin{array}{l}0.0002 \\
{[0.015]}\end{array}$ & $\begin{array}{l}-0.006 \\
{[0.014]}\end{array}$ \\
\hline Relative price change $i(t-1)$ & $\begin{array}{l}0.085 \\
{[0.066]}\end{array}$ & $\begin{array}{l}0.046 \\
{[0.071]}\end{array}$ & $\begin{array}{l}0.067 \\
{[0.067]}\end{array}$ & $\begin{array}{l}0.114 * \\
{[0.067]}\end{array}$ \\
\hline Mean tangible assets $i(t-1)$ & $\begin{array}{l}0.0004 \\
{[0.001]}\end{array}$ & $\begin{array}{l}0.004 * * * \\
{[0.001]}\end{array}$ & $\begin{array}{l}0.001 \\
{[0.001]}\end{array}$ & $\begin{array}{l}0.001 \\
{[0.001]}\end{array}$ \\
\hline Real interest rate $(t)$ & $\begin{array}{l}0.105 \\
{[0.064]}\end{array}$ & $\begin{array}{l}0.036 \\
{[0.054]}\end{array}$ & $\begin{array}{l}0.088 \\
{[0.060]}\end{array}$ & $\begin{array}{l}0.104 * \\
{[0.059]}\end{array}$ \\
\hline GDP growth rate $(t)$ & $\begin{array}{l}1.666 \\
{[1.033]}\end{array}$ & $\begin{array}{l}0.876 \\
{[0.830]}\end{array}$ & $\begin{array}{l}1.423 \\
{[0.973]}\end{array}$ & $\begin{array}{l}1.621 * \\
{[0.949]}\end{array}$ \\
\hline Real wage growth rate $(t)$ & $\begin{array}{l}-1.203 \\
{[0.820]}\end{array}$ & $\begin{array}{l}0.062 \\
{[0.827]}\end{array}$ & $\begin{array}{l}-0.932 \\
{[0.792]}\end{array}$ & $\begin{array}{l}-1.225 \\
{[0.800]}\end{array}$ \\
\hline Tot employment growth rate $(t)$ & $\begin{array}{l}-0.472 * * * \\
{[0.166]}\end{array}$ & $\begin{array}{l}-0.079 \\
{[0.246]}\end{array}$ & $\begin{array}{l}-0.436^{* * *} \\
{[0.165]}\end{array}$ & $\begin{array}{l}-0.405^{* *} \\
{[0.158]}\end{array}$ \\
\hline Constant & $\begin{array}{l}-0.589 \\
{[0.386]}\end{array}$ & $\begin{array}{l}-0.167 \\
{[0.323]}\end{array}$ & $\begin{array}{l}-0.487 \\
{[0.365]}\end{array}$ & $\begin{array}{l}-0.576 \\
{[0.355]}\end{array}$ \\
\hline Observations & 394 & 394 & 394 & 394 \\
\hline R-squared & 0.12 & 0.12 & & \\
\hline AR1 test ( $p$-value) & & & 0.010 & 0.013 \\
\hline AR2 test ( $p$-value) & & & 0.509 & 0.564 \\
\hline Hansen test ( $p$-value) & & & 0.501 & 0.616 \\
\hline
\end{tabular}

Standard errors (in parentheses) are clustered within NACE 3-digit industries. In the system-GMM regressions, job creation $i(t-1)$ and job destruction $i(t-1)$, or job creation "cont" $i(t-1)$ and job destruction "cont" $i(t-1)$, are instrumented using a full set of their valid time-lags. The other explanatory variables are treated as exogenous. $* * *, * *, *$ indicate significance at 1,5 and $10 \%$, respectively 
Table 7 Regression results for gross flows, with RER changes interacted with the overall openness index

\begin{tabular}{llll}
\hline $\begin{array}{l}\text { Estimation method } \\
\text { Dependent variable } i(t)\end{array}$ & $\begin{array}{l}\text { OLS } \\
\text { Gross flows } \\
(1)\end{array}$ & $\begin{array}{l}\text { Fixed effects } \\
\text { Gross flows } \\
(2)\end{array}$ & $\begin{array}{l}\text { System-CM } \\
\text { Gross flo } \\
(3)\end{array}$ \\
\hline Job creation $i(t-1)$ & 0.104 & $-0.299 * * *$ & 0.001 \\
Job destruction $i(t-1)$ & {$[0.072]$} & {$[0.031]$} & {$[0.068]$} \\
& $0.341^{* * *}$ & 0.102 & $0.255^{* * *}$ \\
{$[0.100]$} & {$[0.070]$} & {$[0.069]$}
\end{tabular}

Job creation "cont" $i(t-1)$

0.005

[0.093]

Job destruction "cont" $i(t-1)$

$0.277 * * *$

Openness_index $i(t) *$ AE $i(t)$

0.285

[0.056]

Openness_index $i(t) *$ AE $i(t)$

[0.283]

[0.350]

0.197

0.257

Openness_index $i(t) * \mathrm{AY}^{*} i(t)$

0.118

$-1.228 *$

[0.286]

[0.202]

RCA $i(t)$

[0.348]

[0.696]

0.011

0.25

Herfindahl index $i(t-1)$

-0.014 *

0.016

[0.364]

[0.258]

Relative price change $i(t-1)$

[0.008]

[0.016]

$-0.013$

$-0.008 * *$

$-0.0001$

0.209*

[0.008]

[0.004]

[0.025]

[0.121]

0.021

$-0.029 *$

0.202

0.081

[0.030]

[0.016]

[0.140]

[0.161]

0.165

0.062

[0.147]

[0.067]

Mean tangible assets $i(t-1)$

$-0.001$

0.002

$-0.001$

$-0.001$

[0.001]

[0.003]

[0.001]

[0.001]

Real interest rate $(t)$

$0.262 * * *$

0.087

$0.224 * *$

$0.126^{*}$

GDP growth rate (t)

[0.099]

[0.090]

[0.090]

[0.069]

$4.094 * *$

$2.207 *$

$3.615 * *$

$1.852 *$

[1.650]

[1.323]

[1.492]

[1.108]

Real wage growth rate $(t)$

$-3.245^{* *} \quad-0.656$

$-2.689 * *$

$-1.555^{*}$

[1.302]

[1.359]

[1.221]

[0.903]

Tot employment growth rate $(t)$

Constant

$-0.122$

0.531

$-0.043$

$-0.195$

[0.259]

[0.326]

[0.256]

[0.186]

$-1.470 * *$

$-0.451$

$-1.239 * *$

$-0.662$

[0.596]

[0.541]

Observations

394

394

[0.542]

[0.418]

R-squared

0.08

0.14 394

AR1 test ( $p$-value)

$$
\begin{aligned}
& 0.001 \\
& 0.527
\end{aligned}
$$$$
0.010
$$

AR2 test ( $p$-value)

0.413

Hansen test ( $p$-value)

0.243

0.111

Standard errors (in parentheses) are clustered within NACE 3-digit industries. In the system-GMM regressions, job creation $i(t-1)$ and job destruction $i(t-1)$, or job creation "cont" $i(t-1)$ and job destruction "cont" $i(t-1)$, are instrumented using a full set of their valid time-lags. The other explanatory variables are treated as exogenous. ***, **, * indicate significance at 1,5 and $10 \%$, respectively 
Table 8 Impact of a one standard deviation real appreciation (1.6\%) for industries at different levels of openness to trade

\begin{tabular}{llll}
\hline $\begin{array}{l}\text { Openness } \\
\text { percentile }\end{array}$ & $\begin{array}{l}\text { overall openness } \\
\text { index value }\end{array}$ & $\begin{array}{l}\text { Impact on net } \\
\text { flows }(\%)\end{array}$ & $\begin{array}{l}\text { Impact on job } \\
\text { destruction (\%) }\end{array}$ \\
\hline 10 & 0.58 & -0.5 & 0.4 \\
50 & 1.10 & -1.0 & 0.7 \\
90 & 1.51 & -1.4 & 0.9 \\
\hline
\end{tabular}

The computation of the effects is based on the coefficients of "Openness_Index $i(t) * \Delta \mathrm{E} i(t)$ " estimated by system-GMM, i.e., column 3 of Tables 4 and 6

estimates, I employ the Blundell and Bond (1998) one-step system-GMM estimator, where Job_Creation $\left.{ }_{i(t}-1\right)$ and Job_Destruction $(t-1)$ are always instrumented using their second and higher-order lags. ${ }^{29}$ Since such instruments are only valid if errors are not autocorrelated, the appropriate autocorrelation tests are reported. As these tests are referred to first-differenced errors, first-order autocorrelation is to be expected, while the absence of second-order autocorrelation is needed. In addition, for all the system-GMM regressions I also report the results of the Hansen test for overidentifying restrictions.

Given all the above considerations, in line with Moser et al. (2010), all the regressions are estimated in three different ways: (1) OLS with no industry fixed effects, (2) OLS augmented by 3-digit industry fixed effects, (3) Blundell and Bond (1998) system-GMM estimation. This allows to compare different estimates, and check whether the Blundell and Bond (1998) estimator is correcting biases as expected from theory. In all the estimations, standard errors are corrected for clustering within 3-digit industries. Results are discussed in the next section.

\subsection{Estimation results}

Table 4 reports the econometric results from the estimation of Eq. 13, using Net_Flow $_{i(t)}$ as the dependent variable. In particular, column 1 displays the outcome of the simple OLS regression, with no industry fixed effects. Column 2 reports the results from the OLS regression augmented by 3-digit industry fixed effects. Column 3 reports the results from the Blundell and Bond (1998) system-GMM estimation. Finally, column 4 reports system-GMM results obtained using the "cont" measures of Net_Flow it $_{t}$ instead of the "standard" ones. Such "cont" measures are computed as explained in Sect. 2.1, by excluding the contribution of entering and exiting firms to job creation and job destruction in each year. Column 4 thus provides a robustness check against possible biases related to firm entry and exit in the Amadeus sample. Tables 5, 6, and 7 are structured in the same way as Table 4, considering as a dependent variable Job_Creation ${ }_{i(t)}, J_{o b}$ Destruction $_{i(t)}$ and Gross_Flow ${ }_{i(t)}$, respectively. In all cases, the industry-specific RER variation

\footnotetext{
29 Variables are transformed in forward orthogonal deviations (see Roodman 2009).
} 


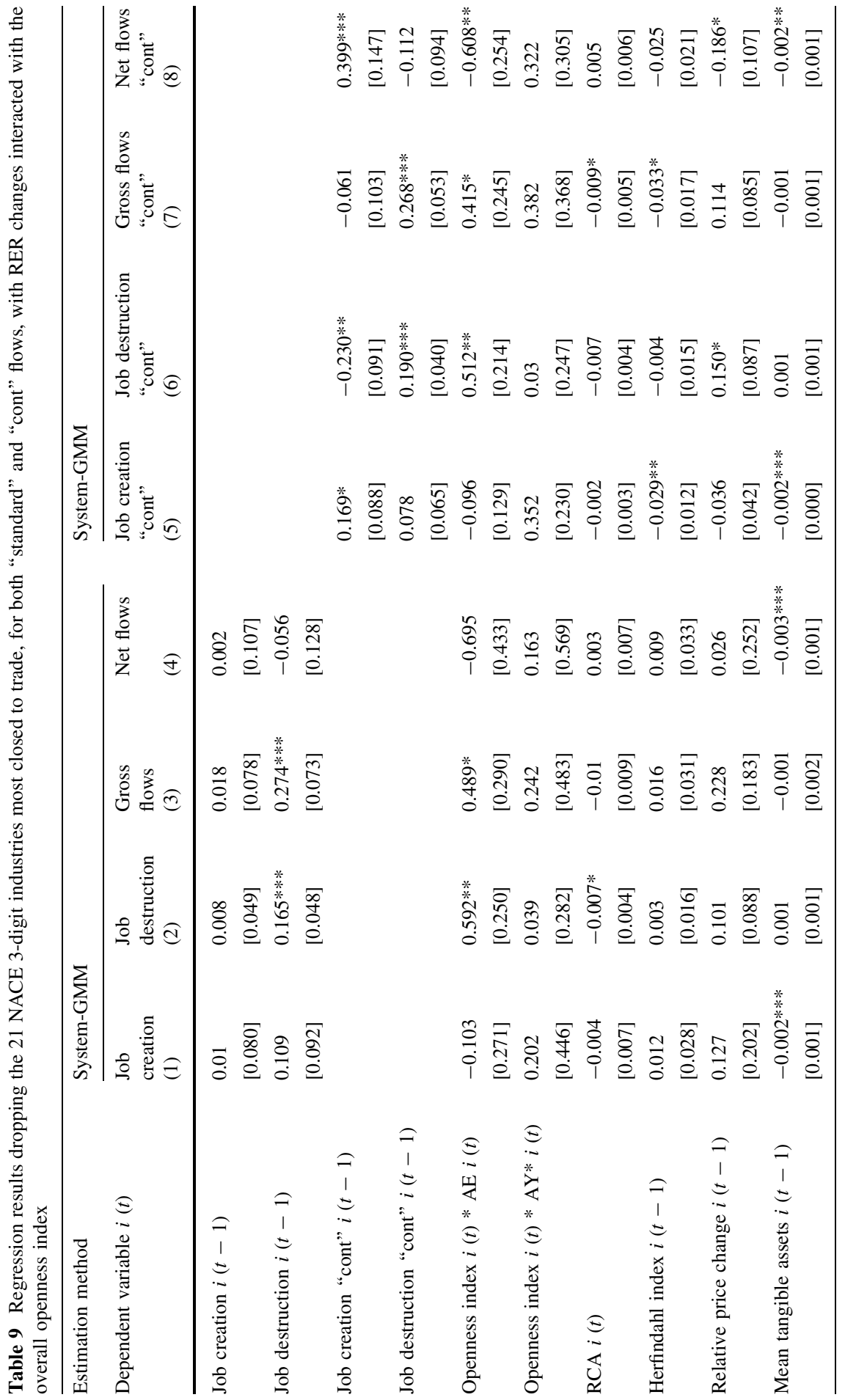




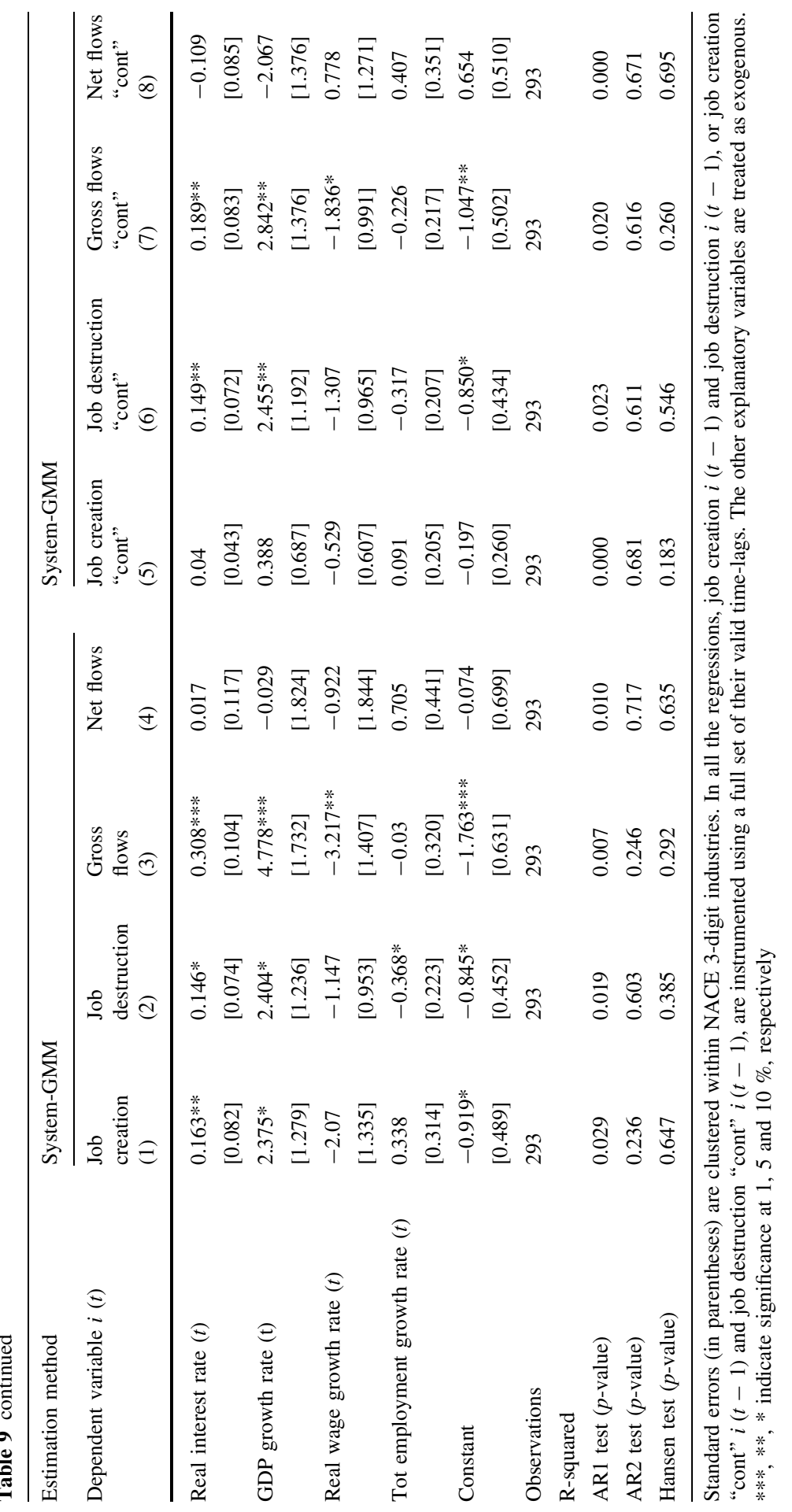


$\left(\Delta E_{i(t)}\right)$ is interacted with the overall openness index $($ Openness_Index $i(t)) .{ }^{30}$ The discussion will mainly focus on the system-GMM results, where the dynamic nature of the specifications is properly addressed.

First, the results indicate that a real appreciation has a negative impact on net employment growth, and that this impact is magnified by increasing levels of overall openness to trade. Second, concerning the adjustment margin, the net employment effect is strongly driven by an increase in job destruction, while job creation is not significantly affected. The magnitude of the effects is relatively small, in line with earlier evidence by Gourinchas (1999), Klein et al. (2003a) and Moser et al. (2010). In particular, Table 8 shows the impact of a one standard deviation real appreciation $(1.6 \%)$ on net employment growth and job destruction, for industries characterized by different levels of openness to trade. The computation of the effects is based on the estimated coefficients for Openness_Index $i(t) * \Delta E_{i(t)}$, as reported in column 3 of Tables 4 and 6 . When focusing on the median industry in terms of trade exposure, a one standard deviation real appreciation determines a decrease in net employment growth by $1 \%$, driven by a $0.7 \%$ increase in job destruction (about 3,900 jobs lost, when evaluated on the whole manufacturing workforce in Table 11 in the "Appendix", just as an example). To have an idea of the growth in the effects as the level of trade exposure increases, we have that the impact for the industry at the 90th percentile of openness is more than twice the one for the relatively closed industry at the 10th percentile. The results do not qualitatively change when considering "cont" job flows instead of the "standard" ones: if anything, the coefficient for the impact on net flows is more precisely identified. However, the magnitude of the effects is slightly lower than for standard flows. This is consistent with the fact that a real appreciation may force some firms to exit, as found by Baldwin and Yan (2011) and Moser et al. (2010). Therefore, when focusing only on job destruction by continuing firms, I am capturing the lower bound of the total effect of a RER appreciation on job destruction and net employment growth. As an additional robustness check, in the spirit of Gourinchas (1999), I have re-estimated all the regressions on a subsample of relatively more open NACE 2-digit industries. This has been done by dropping the 213 -digit industries belonging to the $25 \%$ most closed 2-digit industries. ${ }^{31}$ The main results, reported in Table 9, are qualitatively unaffected.

As expected from theory, when looking at the estimated coefficients for $J_{o b \_C r e a t i o n}(t-1)$ (in the first three columns of Table 5) and Job_Destruction ${ }_{i(t-1)}$ (in the first three columns of Table 6), we can see that the system-GMM estimates are in the middle between the OLS and the FE ones. In particular, the OLS coefficients are overestimated while the FE ones are underestimated. This is reassuring with respect to the appropriateness of the system-GMM estimation.

\footnotetext{
30 The regressions are based on 394 observations. The average number of observations per 3-digit industry is 4.8. The 3-digit industries that tend to be more unbalanced are the ones belonging to the 2-digit industries 32 (Manufacture of radio, television and communication equipment and apparatus) and 35 (Manufacture of other transport equipment), with an average of 3.7 observations.

31 The relative openness of 2-digit industries has been evaluated based on the average level of the overall openness index over the time span.
} 
Moreover, for each of the system-GMM regressions, the $\mathrm{AR}(2)$ test does not reject the null hypothesis of no second-order autocorrelation of the residuals in first differences, and the Hansen test is also supporting the validity of the instruments. Thus one can be confident that the dynamic panel estimator is well specified.

Overall, when focusing on the system-GMM results in column 3 across Tables 4, 5, 6 and 7, job creation and net flows do not appear to be related to lagged levels of job creation and destruction. Instead, job destruction and gross flows are positively related to past levels of job destruction, and thus may react weakly to past RER changes. Concerning the other industry level controls, higher levels of mean tangible assets seem to be related to lower job creation and net employment growth. Instead, the coefficients for the foreign trade-weighted GDP growth, the real comparative advantage, the Herfindahl Index and the relative price change are not found to be significant. As to macro-controls, job creation and gross flows are positively related to the real interest rate and GDP growth. Gross flows are instead negatively related with increases in real wages. Finally, increases in total manufacturing employment are positively related with job creation and net flows, and negatively related with job destruction at the 3-digit industry level.

The main results are not qualitatively changed when interacting the RER movements $\left(\Delta E_{i(t)}\right)$ with the alternative measures of trade exposure: import competition index and export intensity index (see Table 16 in the "Appendix"). As a further robustness check, all the estimations have been repeated by dropping the macro-controls and including year dummies. The results are unchanged. ${ }^{32}$ Finally, results are not likely to suffer from endogeneity problems concerning the main variable of interest: Openness_Index $x_{i(t)} * \Delta E_{i(t)}$. Indeed, as also discussed in previous studies, all the employed trade data are lagged, and the bilateral real exchange rates are determined at the country (and euro area) level, while job flows are studied at a highly disaggregated (and country-specific) 3-digit industry level. The results are discussed in the next section.

\subsection{Discussion}

The main finding of the econometric analysis is the following: an RER appreciation has a negative impact on net employment growth at the industry level, and this impact is magnified by increasing levels of trade exposure. As to the adjustment margin, the decrease in net employment growth is driven by an increase in job destruction, while job creation is not significantly affected by RER movements. Such evidence of a job destruction-driven adjustment is in line with earlier findings by Klein et al. (2003a) for the US. In contrast, my results depart from previous evidence for other EU countries. In fact, Gourinchas (1999) and Moser et al. (2010)

\footnotetext{
$\overline{32}$ They are available upon request.
} 
have found that job creation plays a major role in the reaction to RER changes, in France and Germany, respectively. ${ }^{33}$

Moser et al. (2010) attributed the different results for the US and Germany to differences in the labor market institutions, and a similar argument could be put forward for France. As a matter of fact, France and Germany display much higher levels of employment protection, which makes job destruction difficult and costly for firms. For instance, in 2002, the OECD Overall Index for the Strictness of Employment Protection takes value 3.05 for France and 2.09 for Germany, against a level of 0.21 for the US. In ordinal terms, the US rank first for low-strictness among the 28 surveyed industrialized countries, while France and Germany rank 24th and 17th, respectively. In the interpretation given by Moser et al. (2010), since firing is relatively more costly in France and Germany than in the US, French and German firms do not immediately react to a negative RER shock by destroying jobs, as their US counterparts do; rather, they adjust by creating less new jobs. Now, my results indicate that the adjustment to RER shocks in Belgium works through the job destruction margin, in line with the US and differently from France and Germany. Such differences between Belgium and the other two European countries are not likely to be driven by differences in the labor market institutions. Indeed, Belgium is also characterized by a relatively high level of labor market rigidities. For instance, the above-cited OECD Index in 2002 is equal to 2.18 for Belgium, slightly above the German figure. Hence, the explanation for the uncovered differences has to be found elsewhere.

In my interpretation, my findings may be explained by the fact that Belgium, differently from France and Germany, is a small open economy, where firms face much higher levels of trade exposure. Indeed, as discussed in Sect. 2.2, the trade(in goods)-toGDP ratio is equal to 1.30 for Belgium in 2002, against a value of 0.42 for France and 0.54 for Germany (OECD data). In particular, focusing on the 82 3-digit manufacturing industries in my sample, the lowest yearly figures for both import competition and export intensity are around 0.21 , i.e., well above the minimum thresholds adopted by Gourinchas (1999) for identifying tradable industries in France $(0.13$ and 0.125 for export intensity and import competition, respectively). Overall, Belgian firms operate in a much smaller domestic market than French or German firms, and are more exposed to international trade. As a result, they are forced to be more reactive to shocks hitting their international competitiveness. This may explain why the adjustment to real exchange rate appreciations occurs through the job destruction margin, despite the high level of

\footnotetext{
33 As a necessary premise to the discussion that follows, one should be aware that there are some differences in the type of data and in the employed methodology between my study, Gourinchas (1999), Klein et al. (2003a), and Moser et al. (2010). In terms of data, this paper is close to Gourinchas (1999) and Klein et al. (2003a); in fact it focuses on industry level job flows for the manufacturing sector only, while Moser et al. (2010) use establishment level worker flows, both for manufacturing and for services. In terms of empirical methodology, my approach is instead closer to Klein et al. (2003a) and Moser et al. (2010). In particular, drawing on the theoretical model by Klein et al. (2003a), the specifications include RER changes, rather than levels, as well as a set of industry level controls which are not included by Gourinchas (1999). Moreover, my analysis covers all the manufacturing industries for which data are available, and the cross-industry heterogeneity in trade exposure is controlled for. Instead, Gourinchas (1999) focuses only on the subset of industries that are most open to trade, as discussed later in this section, without allowing the impact of real exchange rates to depend on the industry-specific level of trade exposure.
} 
employment protection. In fact, even though destroying jobs is costly for Belgian firms, the cost of failing to adjust timely to RER shocks is likely to be even higher, in terms of reduced profits, due to the very high level of trade exposure. Overall, these results highlight the importance of studying the adjustment to RER changes in different country-contexts, where job flow responses may be very differentiated. The main contribution of this paper, building on earlier studies, is that of shedding light on the differences between a small open economy and relatively larger EU countries, which are characterized by similar levels of labor market rigidity.

Some other results are worth discussing in terms of industry level controls, focusing on the system-GMM results. In particular, consistent with expectations from previous studies, I find some evidence of lower job creation and net employment growth in industries characterized by high barriers to entry, as measured by mean tangible assets. On the contrary, there is no evidence of the expected link between comparative advantage and job flows. This may be due to the employed measure of revealed comparative advantage, as introduced in Sect. 4.2. In fact, as domestic firms increase their imports of intermediates from abroad, in order to exploit cost and/or quality advantages in foreign countries, competitiveness gains within an industry may go hand in hand with a decrease in the employed RCA measure (Amiti and Konings 2007; Kasahara and Rodrigue 2008; Halpern et al. 2011). This calls for the development of refined indicators of revealed comparative advantage, a task that is beyond the scope of this paper.

\section{Conclusion}

This paper has investigated the impact of RER movements on job flows, focusing on the manufacturing sector of a small open economy characterized by significant labor market rigidities: Belgium. I have found that real appreciations have a negative impact on net employment growth through an increase in job destruction, while job creation is not significantly affected. While being in line with previous empirical evidence on the US, my results depart from earlier findings for larger EU countries, in particular France and Germany, where the adjustment to RER shocks has been found to occur mainly through the job creation margin. These differences may be attributed to the fact that Belgium is a small open economy, where firms face much higher levels of trade exposure.

Being able to identify the adjustment margin behind the net flow effects is of fundamental importance for welfare analysis. Indeed, numerically equivalent increases in job destruction and reductions in job creation may have very different welfare implications. For instance, while an increase in job destruction is likely to involve the displacement of high-wage and older workers, a reduction in job creation is more likely to slow down the accumulation of human capital, by increasing the duration of unemployment (Davis et al. 1996; Klein et al. 2003a, b). A thorough welfare analysis is beyond the scope of this paper, and constitutes an interesting avenue for further research.

Acknowledgments I am grateful to Carlo Altomonte, Rosario Crino', Jan De Loecker, Maarten Goos, Bas Karreman, Joep Konings, Enrico Pennings, Damiaan Persyn, Leo Sleuwaegen, Stijn Vanormelingen and an anonymous referee for very useful comments and suggestions. This paper has also benefited from presentations at LICOS-Catholic University of Leuven, Bocconi University and Polytechnic University of Milan. The usual disclaimer applies. 
Open Access This article is distributed under the terms of the Creative Commons Attribution License which permits any use, distribution, and reproduction in any medium, provided the original author(s) and the source are credited.

\section{Appendix}

The following tables contain descriptive information on the firm level data set which has been employed in the job reallocation analysis, as well as some additional results.

See Tables 10, 11, 12, 13, 14, 15 and 16.

Table 10 Sample firms by NACE 3-digit industry

\begin{tabular}{|c|c|c|}
\hline Description & NACE 3 & No. of firms \\
\hline Meat and meat products (production/processing/preserving) & 151 & 403 \\
\hline Fish and fish products (processing/preserving) & 152 & 29 \\
\hline Fruit and vegetables (processing/preserving) & 153 & 80 \\
\hline Vegetable and animal oils and fats & 154 & 28 \\
\hline Dairy products & 155 & 131 \\
\hline Grain mill, starches and starch products & 156 & 78 \\
\hline Prepared animal feeds & 157 & 82 \\
\hline Other food products & 158 & 1,735 \\
\hline Beverages & 159 & 152 \\
\hline Tobacco products & 160 & 25 \\
\hline Preparation and spinning of textile fibres & 171 & 160 \\
\hline Textile weaving & 172 & 150 \\
\hline Made-up textile articles (except apparel) & 174 & 186 \\
\hline Other textiles & 175 & 252 \\
\hline Knitted and crocheted fabrics & 176 & 33 \\
\hline Knitted and crocheted articles & 177 & 26 \\
\hline Leather clothes & 181 & 9 \\
\hline Other wearing apparel and accessories & 182 & 492 \\
\hline Dressing and dyeing of fur; articles of fur & 183 & 19 \\
\hline Wood sawmilling, planing and impregnation & 201 & 228 \\
\hline Veneer sheets, plywood and other panels and boards & 202 & 70 \\
\hline Builders carpentry and joinery & 203 & 260 \\
\hline Wooden containers & 204 & 76 \\
\hline Other wood products; cork articles, straw and plaiting materials & 205 & 114 \\
\hline Pulp, paper and paperboard & 211 & 77 \\
\hline Articles of paper and paperboard & 212 & 196 \\
\hline Publishing & 221 & 515 \\
\hline Printing and related services & 222 & 1,580 \\
\hline Basic chemicals & 241 & 182 \\
\hline Paints, varnishes and similar, printing ink and mastics & 243 & 93 \\
\hline Pharmaceuticals, medicinal chemicals, botanical products & 244 & 90 \\
\hline
\end{tabular}


Table 10 continued

\begin{tabular}{|c|c|c|}
\hline Description & NACE 3 & No. of firms \\
\hline Soap, detergents, perfumes, cleaning and toilet preparations & 245 & 124 \\
\hline Other chemical products & 246 & 80 \\
\hline Man-made fibres & 247 & 32 \\
\hline Rubber products & 251 & 92 \\
\hline Plastic products & 252 & 340 \\
\hline Glass and glass products & 261 & 145 \\
\hline Ceramic products & 262 & 51 \\
\hline Ceramic tiles and flags & 263 & 12 \\
\hline Bricks, tiles and construction products in baked clay & 264 & 53 \\
\hline Cement, lime and plaster & 265 & 12 \\
\hline Concrete, plaster and cement articles & 266 & 391 \\
\hline Ornamental and building stone & 267 & 342 \\
\hline Other non-metallic mineral products & 268 & 33 \\
\hline Tubes & 272 & 21 \\
\hline Other first processing of iron and steel & 273 & 20 \\
\hline Basic precious and non-ferrous metals & 274 & 43 \\
\hline Structural metal products & 281 & 1,135 \\
\hline Tanks, containers of metal, radiators and boilers & 282 & 117 \\
\hline Steam generators & 283 & 14 \\
\hline Cutlery, tools and general hardware & 286 & 82 \\
\hline Other fabricated metal products & 287 & 325 \\
\hline Machinery for production and use of mechanical power & 291 & 117 \\
\hline Other general purpose machinery & 292 & 410 \\
\hline Agricultural and forestry machinery & 293 & 115 \\
\hline Machinetools & 294 & 176 \\
\hline Other special purpose machinery & 295 & 229 \\
\hline Domestic appliances n.e.c. & 297 & 44 \\
\hline Office machinery and computers & 300 & 85 \\
\hline Electric motors, generators and transformers & 311 & 107 \\
\hline Electricity distribution and control apparatus & 312 & 46 \\
\hline Insulated wire and cable & 313 & 18 \\
\hline Lighting equipment and electric lamps & 315 & 113 \\
\hline Electrical equipment n.e.c. & 316 & 156 \\
\hline Electronic valves, tubes and other components & 321 & 72 \\
\hline TV-radio transmitters, apparatus for line phone/telegraph & 322 & 34 \\
\hline TV-radio receivers, apparatus for sound/video rec. etc & 323 & 69 \\
\hline Medical and surgical equipment, orthopaedic appliances & 331 & 307 \\
\hline Instruments and appliances for measuring, checking etc. & 332 & 63 \\
\hline Optical instruments and photographic equipment & 334 & 23 \\
\hline Watches and clocks & 335 & 5 \\
\hline Motor vehicles & 341 & 30 \\
\hline Bodies for motor vehicles, trailers and semi-trailers & 342 & 145 \\
\hline
\end{tabular}


Table 10 continued

\begin{tabular}{lrr}
\hline Description & NACE 3 & No. of firms \\
\hline Parts and accessories for motor vehicles and engines & 343 & 80 \\
Railway and tramway locomotives and rolling stock & 352 & 8 \\
Aircraft and spacecraft & 353 & 20 \\
Motorcycles and bicycles & 354 & 15 \\
Furniture & 361 & 874 \\
Musical instruments & 363 & 20 \\
Sports goods & 364 & 16 \\
Games and toys & 365 & 19 \\
Manufacturing n.e.c. & 366 & 168 \\
Total & & 14,599
\end{tabular}

Table 11 Sample coverage, based on the total sample stock of employees

\begin{tabular}{llll}
\hline Year & Sample stock & Official figure & Coverage (\%) \\
\hline 1996 & 340,313 & 559,001 & 61 \\
1997 & 348,008 & 548,317 & 63 \\
1998 & 358,247 & 539,788 & 66 \\
1999 & 367,202 & 541,719 & 68 \\
2000 & 381,004 & 553,495 & 69 \\
2001 & 394,075 & 557,566 & 71 \\
2002 & 390,577 & n.a. & 66 \\
Average coverage & & & \\
\hline
\end{tabular}

Official figures are sourced from the Eurostat Structural Business Statistics Database

Table 12 Sample split and average job flows per firm-size categories

\begin{tabular}{lccllll}
\hline $\begin{array}{l}\text { Firm size } \\
\text { (no. of employees) }\end{array}$ & $\begin{array}{l}\text { No. of } \\
\text { firms }\end{array}$ & $\begin{array}{l}\text { Rate of total number } \\
\text { of employees (\%) }\end{array}$ & $\begin{array}{l}\text { Job } \\
\text { creation }\end{array}$ & $\begin{array}{l}\text { Job } \\
\text { destruction }\end{array}$ & $\begin{array}{l}\text { Net } \\
\text { flows }\end{array}$ & $\begin{array}{l}\text { Gross } \\
\text { flows }\end{array}$ \\
\hline$\leq 5$ & 7,411 & 3 & 0.127 & 0.121 & 0.006 & 0.247 \\
$5-25$ & 4,498 & 13 & 0.089 & 0.065 & 0.024 & 0.153 \\
$25-100$ & 2,001 & 24 & 0.069 & 0.042 & 0.028 & 0.111 \\
$>100$ & 689 & 60 & 0.051 & 0.038 & 0.013 & 0.089 \\
\hline
\end{tabular}

Each firm is classified in one of the four categories according to its average size over time. Job flow figures are averages over time

Table 13 Firm level employment descriptive statistics

\begin{tabular}{lccccr}
\hline & Obs. & Mean & SD & Min & Max \\
\hline All sample & 79,682 & 32 & 147.26 & 1 & 7,765 \\
Entering firms & 1,941 & 15.5 & 75.59 & 1 & 2,009 \\
Exiting firms & 2,150 & 4.3 & 19.28 & 1 & 456 \\
\hline
\end{tabular}

Figures for entering and exiting firms refer to the year in which entry/exit takes place 
Table 14 Sample firms' entry and exit rates

\begin{tabular}{llllll}
\hline Year & Entry & Exit & No. of firms & Entry rate $(\%)$ & Exit rate $(\%)$ \\
\hline 1997 & 331 & 411 & 12,165 & 3 & 3 \\
1998 & 320 & 284 & 12,361 & 3 & 2 \\
1999 & 335 & 269 & 12,521 & 3 & 2 \\
2000 & 324 & 298 & 12,627 & 3 & 2 \\
2001 & 344 & 379 & 12,562 & 3 & 3 \\
2002 & 287 & 509 & 12,110 & 2 & 4 \\
Average & & & & 3 & 3 \\
\hline
\end{tabular}

Table 15 Average job flow rates per NACE 3-digit industry (see Table 10 for a of the industries)

\begin{tabular}{|c|c|c|c|c|c|}
\hline NACE 3 & Job creation & Job destruction & Net flows & Gross flows & Excess flows \\
\hline 152 & 0.089 & 0.030 & 0.059 & 0.119 & 0.059 \\
\hline 153 & 0.074 & 0.041 & 0.033 & 0.115 & 0.068 \\
\hline 154 & 0.043 & 0.083 & -0.040 & 0.127 & 0.059 \\
\hline 155 & 0.050 & 0.038 & 0.011 & 0.088 & 0.067 \\
\hline 156 & 0.023 & 0.031 & -0.008 & 0.054 & 0.036 \\
\hline 157 & 0.077 & 0.045 & 0.031 & 0.122 & 0.072 \\
\hline 158 & 0.068 & 0.050 & 0.018 & 0.119 & 0.101 \\
\hline 159 & 0.029 & 0.030 & -0.001 & 0.058 & 0.050 \\
\hline 160 & 0.042 & 0.041 & 0.002 & 0.083 & 0.046 \\
\hline 171 & 0.056 & 0.043 & 0.013 & 0.100 & 0.068 \\
\hline 172 & 0.052 & 0.038 & 0.014 & 0.091 & 0.060 \\
\hline 174 & 0.077 & 0.043 & 0.034 & 0.120 & 0.086 \\
\hline 175 & 0.064 & 0.043 & 0.021 & 0.107 & 0.080 \\
\hline 176 & 0.044 & 0.058 & -0.014 & 0.102 & 0.083 \\
\hline 177 & 0.053 & 0.052 & 0.001 & 0.105 & 0.074 \\
\hline 181 & 0.070 & 0.052 & 0.018 & 0.122 & 0.041 \\
\hline 182 & 0.032 & 0.087 & -0.055 & 0.119 & 0.064 \\
\hline 183 & 0.067 & 0.104 & -0.037 & 0.172 & 0.066 \\
\hline 201 & 0.065 & 0.052 & 0.013 & 0.116 & 0.103 \\
\hline 202 & 0.089 & 0.037 & 0.053 & 0.126 & 0.072 \\
\hline 203 & 0.087 & 0.049 & 0.038 & 0.136 & 0.092 \\
\hline 204 & 0.080 & 0.055 & 0.025 & 0.135 & 0.100 \\
\hline 205 & 0.068 & 0.058 & 0.010 & 0.125 & 0.104 \\
\hline 211 & 0.028 & 0.035 & -0.007 & 0.063 & 0.045 \\
\hline 212 & 0.052 & 0.034 & 0.018 & 0.086 & 0.064 \\
\hline 221 & 0.099 & 0.066 & 0.033 & 0.165 & 0.120 \\
\hline 222 & 0.078 & 0.060 & 0.018 & 0.138 & 0.098 \\
\hline 241 & 0.044 & 0.024 & 0.021 & 0.068 & 0.041 \\
\hline 243 & 0.051 & 0.033 & 0.018 & 0.083 & 0.061 \\
\hline 244 & 0.066 & 0.018 & 0.048 & 0.083 & 0.035 \\
\hline 245 & 0.098 & 0.045 & 0.052 & 0.143 & 0.078 \\
\hline 246 & 0.075 & 0.025 & 0.051 & 0.100 & 0.049 \\
\hline 247 & 0.046 & 0.037 & 0.008 & 0.083 & 0.061 \\
\hline 251 & 0.053 & 0.065 & -0.013 & 0.118 & 0.057 \\
\hline
\end{tabular}


Table 15 continued

\begin{tabular}{|c|c|c|c|c|c|}
\hline NACE 3 & Job creation & Job destruction & Net flows & Gross flows & Excess flows \\
\hline 252 & 0.092 & 0.042 & 0.050 & 0.135 & 0.080 \\
\hline 261 & 0.087 & 0.037 & 0.049 & 0.124 & 0.072 \\
\hline 262 & 0.048 & 0.051 & -0.003 & 0.099 & 0.064 \\
\hline 263 & 0.125 & 0.046 & 0.079 & 0.171 & 0.083 \\
\hline 264 & 0.048 & 0.055 & -0.007 & 0.103 & 0.060 \\
\hline 265 & 0.008 & 0.029 & -0.021 & 0.037 & 0.011 \\
\hline 266 & 0.075 & 0.030 & 0.044 & 0.105 & 0.058 \\
\hline 267 & 0.078 & 0.051 & 0.027 & 0.128 & 0.099 \\
\hline 268 & 0.081 & 0.041 & 0.039 & 0.122 & 0.063 \\
\hline 272 & 0.170 & 0.102 & 0.068 & 0.271 & 0.143 \\
\hline 273 & 0.023 & 0.045 & -0.022 & 0.068 & 0.035 \\
\hline 274 & 0.160 & 0.032 & 0.128 & 0.191 & 0.030 \\
\hline 281 & 0.070 & 0.041 & 0.029 & 0.110 & 0.081 \\
\hline 282 & 0.057 & 0.033 & 0.024 & 0.090 & 0.059 \\
\hline 283 & 0.079 & 0.055 & 0.023 & 0.134 & 0.072 \\
\hline 286 & 0.091 & 0.035 & 0.056 & 0.125 & 0.066 \\
\hline 287 & 0.070 & 0.059 & 0.011 & 0.129 & 0.089 \\
\hline 291 & 0.048 & 0.034 & 0.014 & 0.082 & 0.059 \\
\hline 292 & 0.084 & 0.039 & 0.045 & 0.124 & 0.079 \\
\hline 293 & 0.059 & 0.046 & 0.013 & 0.105 & 0.051 \\
\hline 294 & 0.051 & 0.052 & -0.001 & 0.104 & 0.071 \\
\hline 295 & 0.045 & 0.030 & 0.016 & 0.075 & 0.051 \\
\hline 297 & 0.115 & 0.055 & 0.060 & 0.170 & 0.066 \\
\hline 300 & 0.173 & 0.054 & 0.119 & 0.226 & 0.084 \\
\hline 311 & 0.051 & 0.044 & 0.007 & 0.096 & 0.056 \\
\hline 312 & 0.081 & 0.041 & 0.040 & 0.123 & 0.069 \\
\hline 313 & 0.029 & 0.059 & -0.030 & 0.087 & 0.025 \\
\hline 315 & 0.039 & 0.026 & 0.012 & 0.065 & 0.036 \\
\hline 316 & 0.098 & 0.022 & 0.076 & 0.120 & 0.044 \\
\hline 321 & 0.143 & 0.077 & 0.067 & 0.220 & 0.148 \\
\hline 322 & 0.035 & 0.047 & -0.012 & 0.082 & 0.029 \\
\hline 323 & 0.027 & 0.059 & -0.032 & 0.086 & 0.023 \\
\hline 331 & 0.089 & 0.103 & -0.014 & 0.193 & 0.156 \\
\hline 332 & 0.081 & 0.053 & 0.029 & 0.134 & 0.083 \\
\hline 334 & 0.069 & 0.071 & -0.002 & 0.139 & 0.066 \\
\hline 335 & 0.072 & 0.021 & 0.051 & 0.093 & 0.022 \\
\hline 341 & 0.027 & 0.081 & -0.053 & 0.108 & 0.055 \\
\hline 342 & 0.063 & 0.032 & 0.031 & 0.095 & 0.047 \\
\hline 343 & 0.107 & 0.033 & 0.075 & 0.140 & 0.065 \\
\hline 352 & 0.005 & 0.067 & -0.062 & 0.072 & 0.010 \\
\hline 353 & 0.159 & 0.029 & 0.130 & 0.189 & 0.019 \\
\hline 354 & 0.066 & 0.021 & 0.045 & 0.088 & 0.039 \\
\hline 361 & 0.047 & 0.043 & 0.004 & 0.091 & 0.078 \\
\hline 363 & 0.072 & 0.082 & -0.011 & 0.154 & 0.105 \\
\hline 364 & 0.066 & 0.123 & -0.057 & 0.189 & 0.081 \\
\hline 365 & 0.047 & 0.066 & -0.020 & 0.113 & 0.033 \\
\hline 366 & 0.095 & 0.047 & 0.047 & 0.142 & 0.094 \\
\hline
\end{tabular}




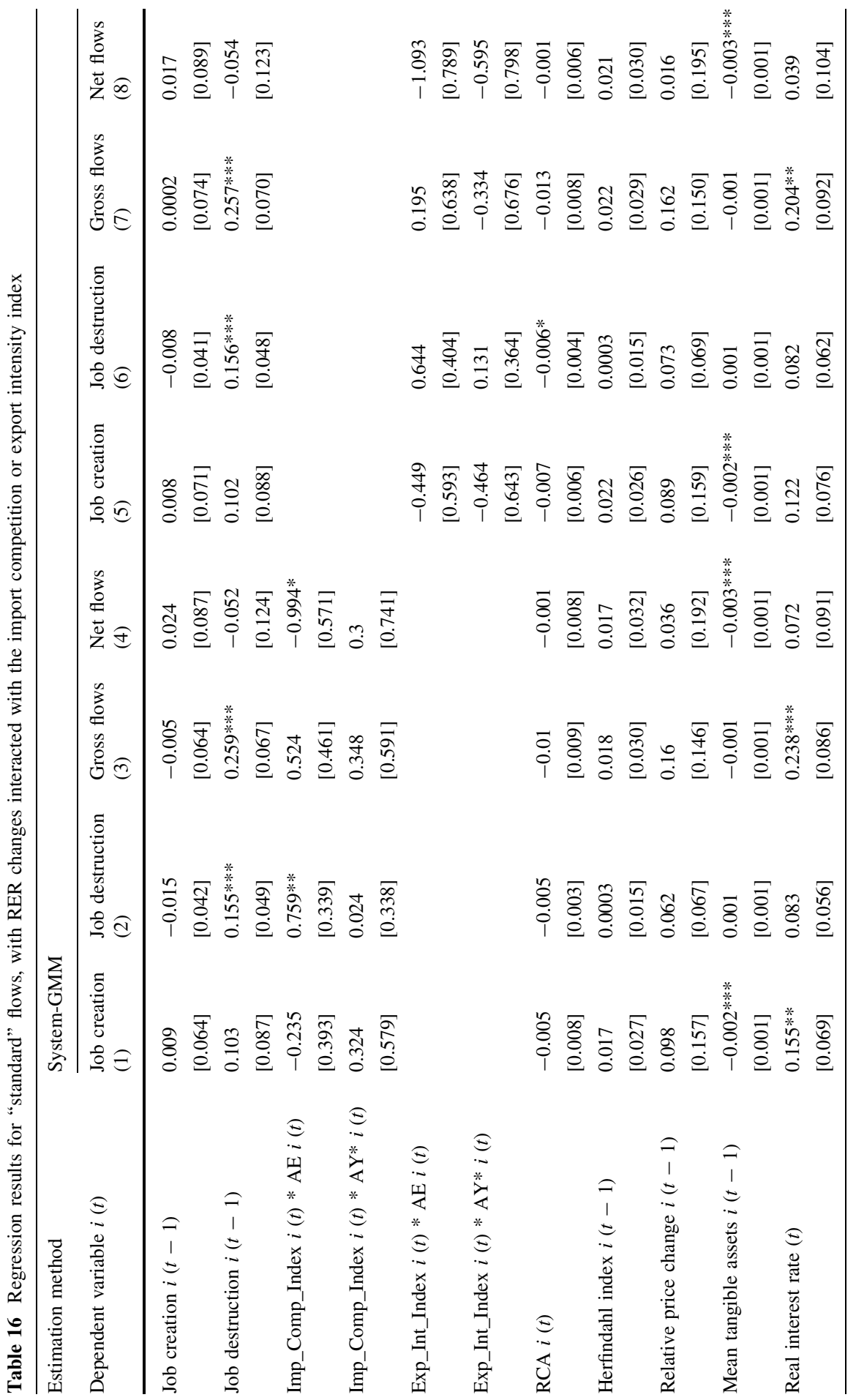




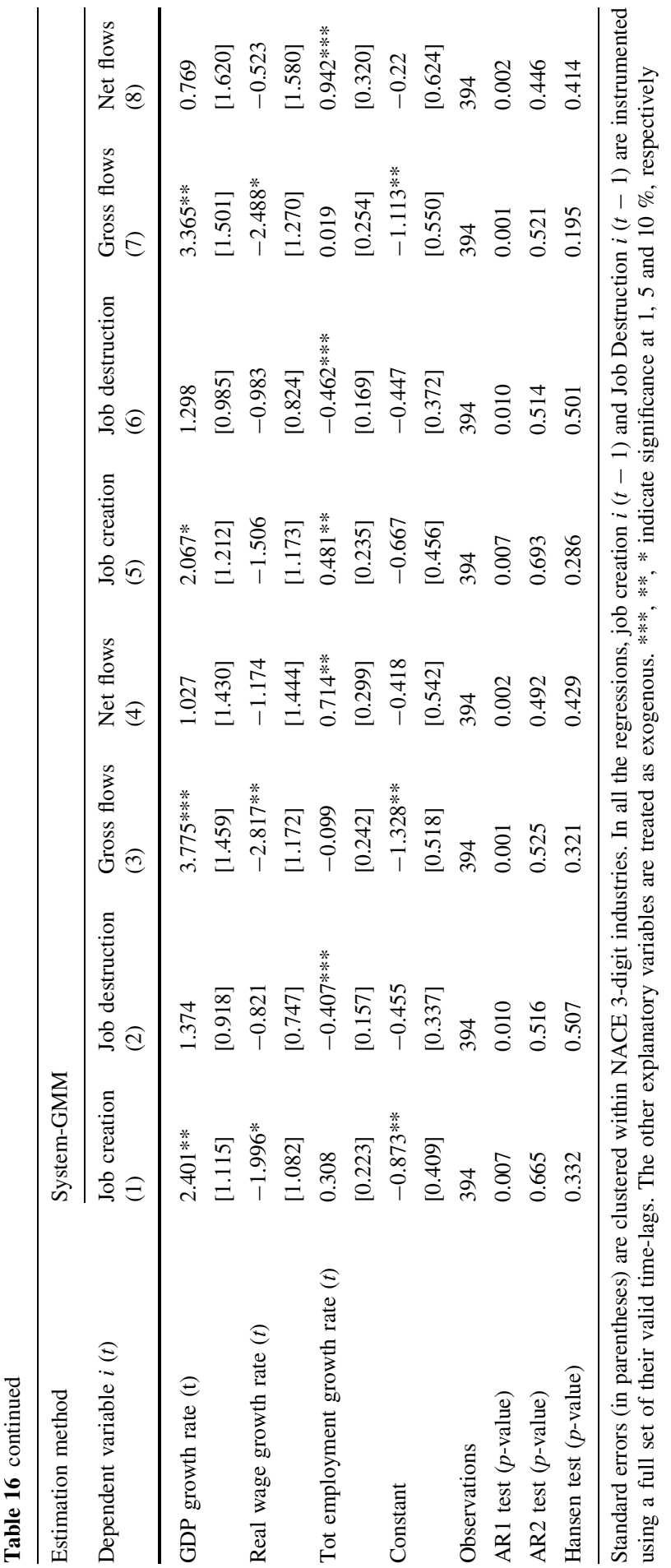




\section{References}

Abraham, F., Konings, J., \& Vanormelingen, S. (2009). The effect of globalization on union bargaining and price-cost margins of firms. Review of World Economics/Weltwirtschaftliches Archiv, 145(1), 13-36.

Amiti, M., \& Konings, J. (2007). Trade liberalization, intermediate inputs, and productivity: Evidence from Indonesia. American Economic Review, 97(5), 1611-1638.

Balassa, B. (1965). Trade liberalisation and 'revealed' comparative advantage. The Manchester School, $33,99-123$.

Baldwin, J. \& Yan, B. (2011). The death of Canadian manufacturing plants: Heterogeneous responses to changes in tariffs and real exchange rates. Review of World Economics/Weltwirtschaftliches Archiv, 147(1), 131-167.

Bernard, A. B., Eaton, J., Jensen, J. B., \& Kortum, S. S. (2003). Plants and productivity in international trade. American Economic Review, 93(4), 1268-1290.

Bernard, A. B., Jensen, J. B., \& Schott, P. K. (2006). Survival of the best fit: Exposure to low wage countries and the (uneven) growth of US manufacturing plants. Journal of International Economics, 68(1), 219-237.

Bernard, A. B., Jensen, J. B., Redding, S. J., \& Schott, P. K. (2007a). Firms in international trade. Journal of Economic Perspectives, 21(3), 105-130.

Bernard, A. B., Redding, S. J., \& Schott, P. K. (2007b). Comparative advantage and heterogeneous firms. Review of Economic Studies, 74, 31-66.

Bertrand, M., \& Kramarz, F. (2002). Does entry regulation hinder job creation? Evidence from the French retail industry. Quarterly Journal of Economics, 117(4), 1369-1413.

Blundell, R., \& Bond, S. (1998). Initial conditions and moment restrictions in dynamic panel data models. Journal of Econometrics, 87(1), 115-143

Blanchard, O., \& Giavazzi, F. (2003). Macroeconomic effects of regulation and deregulation in goods and labor markets. Quarterly Journal of Economics, 118(3), 879-907.

Boeri, T., Nicoletti, G., \& Scarpetta, S. (2000). Regulation and labour market performance (CEPR Discussion Papers, No. 2420). London: Centre for Economic Policy Research.

Branson, W., \& Love, J. (1988). United States manufacturing and the real exchange rate. In Marston, R. (Ed.) Misalignment of exchange rates: Effects on trade and industry (pp. 241-276). Chicago, IL: University of Chicago Press.

Burgess, S., \& Knetter, M. (1998). An international comparison of employment adjustment to exchange rate fluctuations. Review of International Economics, 6(1), 151-163.

Crino', R. (2009). Offshoring, multinationals and labour market: A review of the empirical literature. Journal of Economic Surveys, 23(2), 197-249.

Davis, S. J., \& Haltiwanger, J. C. (1992). Gross job creation, gross job destruction, and employment reallocation. Quarterly Journal of Economics, 107(3), 819-863.

Davis, S. J., Haltiwanger, J. C., \& Schuh, S. (1996). Job creation and destruction. Cambridge, MA: MIT Press.

Eurostat (2012). Structural business statistics. Luxembourg: European Commission.

Geroski, P., Gregg, P., \& van Reenen, J. (1995). Market imperfections and employment (OECD Jobs Study Working Papers, No. 5). Paris: Organisation for Economic Co-operation and Development.

Gómez-Salvador, R., Messina, J., \& Vallanti, G. (2004). Gross job flows and institutions in Europe. Labour Economics, 11(4), 469-485.

Gourinchas, P. (1998). Exchange rates and jobs: What do we learn from job flows? NBER Macroeconomics Annual, 1998, 153-207.

Gourinchas, P. (1999). Exchange rates do matter: French job reallocation and exchange rate turbulence, 1984-1992. European Economic Review, 43(7), 1279-1316.

Halpern, L., Koren, M., \& Szeidl, A. (2011). Imported inputs and productivity. Mimeo: University of California Berkeley.

Kasahara, H., \& Rodrigue, J. (2008). Does the use of imported intermediates increase productivity? Plantlevel evidence. Journal of Development Economics, 87(1), 106-118.

Khandelwal, A. (2010). The long and short (of) quality ladders. Review of Economic Studies, 77(4), 1450-1476.

Klein, M., Schuh, S., \& Triest, R. K. (2003a). Job creation, job destruction, and the real exchange rate. Journal of International Economics, 59, 239-265. 
Klein, M., Schuh, S., \& Triest, R. K. (2003b). Job creation, job destruction, and international competition. Kalamazoo, Michigan: W.E. Upjohn Institute for Employment Research.

Konings, J., Kupets, O., \& Lehmann, H. (2003). Gross job flows in Ukraine: Size, ownership and trade effects. Economics of Transition, 11(2), 321-356.

Levinsohn, J. (1999). Employment responses to international liberalization in Chile. Journal of International Economics, 47(2), 321-344.

Mayer, T., \& Ottaviano, G. (2007). The happy few: New facts on the internationalisation of European firms. Bruegel-CEPR EFIM2007 Report, Bruegel Blueprint Series.

Melitz, M. J. (2003). The impact of trade on intra-industry reallocations and aggregate industry productivity. Econometrica, 71, 1695-1725.

Moser, C., Urban, D. M., \& Weder di Mauro, B. (2010). International competitiveness, job creation and job destruction-An establishment level study of German job flows. Journal of International Economics, 80(2), 302-317.

Nickell, S. (1981). Biases in dynamic models with fixed effects. Econometrica, 49(6), 1417-1426.

Ochel, W. (2009). The political economy of two-tier reforms of employment protection in Europe. International Journal of Labour Law and Industrial Relations, 25(3), 237-260.

OECD (2004). Employment outlook. Paris: Organisation for Economic Co-operation and Development.

OECD (2012). Indicators of employment protection. Paris: Organisation for Economic Co-operation and Development.

Peoples, J. (1998). Deregulation and the labor market. Journal of Economic Perspectives, 12(3), 111-130.

Revenga, A. (1992). Exporting jobs? The impact of import competition on employment and wages in U.S. manufacturing. Quarterly Journal of Economics, 107(1), 255-284.

Roodman, D. (2009). How to do xtabond 2: An introduction to difference and system GMM in Stata. Stata Journal, 9(1), 86-136.

Trognon, A. (1978). Miscellaneous asymptotic properties of ordinary least squares and maximum likelihood estimators in dynamic error components models. Annales de l'INSEE, 30/31, 631-657. 